\title{
The extinction of Chiloguembelina cubensis in the Pacific Ocean: implications for defining the base of the Chattian (upper Oligocene)
}

\author{
David J. King ${ }^{1 \star}$ and Bridget S. Wade ${ }^{1}$
}

With 9 figures, 4 plates, 4 tables and 1 appendix

\begin{abstract}
We conducted quantitative biostratigraphic and morphometric studies at two ocean drilling sites in the Pacific Ocean to investigate the extinction of the planktonic foraminifera genus Chiloguembelina, a distinctive biserial genus ranging in the Eocene and Oligocene. The extinction of the last species of the genus, C.cubensis, has historically been used as a correlation event for the base of the Chattian (upper Oligocene; $\sim 28 \mathrm{Ma}$ ). However, the bioevent has been controversial, as some authors have found a well-defined biohorizon, while others have found a decline in abundance with a continuation of $C$.cubensis into the upper Oligocene. This has been reflected in the preference of using the Top Common occurrence $(>5 \%$ of the foraminiferal assemblage) of the species as a correlation event for the boundary. We assessed the utility of C.cubensis as a reliable biohorizon at Ocean Drilling Program Leg 202 Site 1237 (south-east Pacific Ocean) and Integrated Ocean Drilling Program Expedition 320/321 Site U1334 (eastern equatorial Pacific Ocean). At both sites $C$.cubensis is a common and consistent component of early Oligocene planktonic foraminiferal assemblages. An abrupt termination of C.cubensis occurs at Site 1237 in magnetic polarity Subchron C10n.1n (27.89 Ma), while at Site U1334 peak abundances of C.cubensis are recorded in the upper Oligocene within Chron $9 \mathrm{n}$ with a younger datum for the extinction at $\sim 27.15 \mathrm{Ma}$. Therefore, the biostratigraphic utility of the species as a boundary marker for the base of the Chattian remains unclear. We propose that the phrase "C.cubensis crisis" is the most suitable for describing the extinction or decline in abundance of the species in the mid Oligocene, based upon the findings from these two sites and other age calibrated sites. Morphometric analysis of specimen size at the two sites shows a markedly smaller test size at Site 1237 compared with Site U1334, with specimens from the former being on average $1.37 \times$ shorter and $1.45 \times$ thinner. Differences in test size and extinction horizon are possibly controlled by ecological preferences, however, our biochronological compilation of ocean drilling sites does not reveal a latitudinal trend in extinction level.
\end{abstract}

Key words. Planktonic foraminifera, Chattian, GSSP, extinction, size, Oligocene

\section{Introduction}

\subsection{The Geological Time Scale and the Chattian stage}

The geological time scale represents the most widely applied, fundamental and powerful geological tool, splitting the entirety of the Earth's history into compre- hensive divisions of geological time such as eons, eras and periods (Cohen et al. 2013). Each stage is defined at a type locality, the so called Global Boundary Stratotype Section and Point (GSSP) or the "Golden Spike". According to the suitable criteria set out in Remane et al. (1996) several continuous successions must be analysed through the relevant interval, with the

\footnotetext{
Authors' address:

1 Department of Earth Sciences, University College London, Gower Street, London, WC1E 6BT, UK.david.king.13@ucl. ac.uk; b.wade@ucl.ac.uk

* Corresponding author: david.king.13@ucl.ac.uk
} 
most suitable being the candidate section for defining the GSSP. A primary correlation event, and a number of secondary event markers, are required to allow correlation between successions, which can include the first or last occurrence of a given fossils species, including planktonic foraminifera. Planktonic foraminifera are microscopic marine zooplankton which have long been used in biostratigraphy (e.g. Cushman 1924, Cushman and Stainforth 1945, Blow 1969, Berggren et al. 1985, 1995, Berggren and Pearson 2005, Wade et al. 2011), as they make excellent zone fossils due to their abundance in oceanic sediment, widespread geographical range, morphologically distinct shells (tests), and rapid evolution (Wade et al. 2011).

Within the Paleogene, 6 of the 9 stages currently have formally defined GSSP's, while the remaining three all have potential GSSP locations and correlation events (Jovane et al. 2010, Agnini et al. 2011, Wade et al. 2012, Coccioni et al. 2008, 2013). One such stage is the Chattian (mid Oligocene), with the candidate GSSP section being the Umbria-Marche basin, northeast Apennines, Italy. The two most suitable boundary markers are the oxygen isotope increase recorded in benthic foraminifera (Oi-2a interval), or the Top Common occurrence $(>5 \%$ of the planktonic foraminiferal assemblage) of the planktonic foraminifera species
C.cubensis (Coccioni et al. 2008, 2013). The latter of these two potential correlation events is the focus of this study, with two ocean drilling sites being analysed primarily for the extinction level of C.cubensis.

\subsection{Chiloguembelina cubensis}

Chiloguembelina is a distinct genus within the Eocene and Oligocene planktonic foraminifera characterised by biserial tests, relatively small size $(<200 \mu \mathrm{m})$ and a microperforate test wall, as opposed to the more commonly found trochospiral, macroperforate planktonic forms of the Cenozoic (Jenkins 1985, Huber et al. 2006). Chiloguembelina cubensis was first described by Palmer (1934) and was initially placed in the genus of Güembelina, before later being assigned to Chiloguembelina by Beckmann (1957). The species has also previously been assigned to the genus of Streptochilus (Poore and Gosnell 1985). Huber et al. (2006) state that C.cubensis likely evolved from Chiloguembelina ototara during the late Eocene, and marks the last species of the genus. Aclose similarity exists between C.cubensis and C.ototara, with the distinctive troughs and ridges running parallel to long axis of the test, known as striae, on C.cubensis, acting as the main means to differentiate between the two species (Huber et al. 2006).

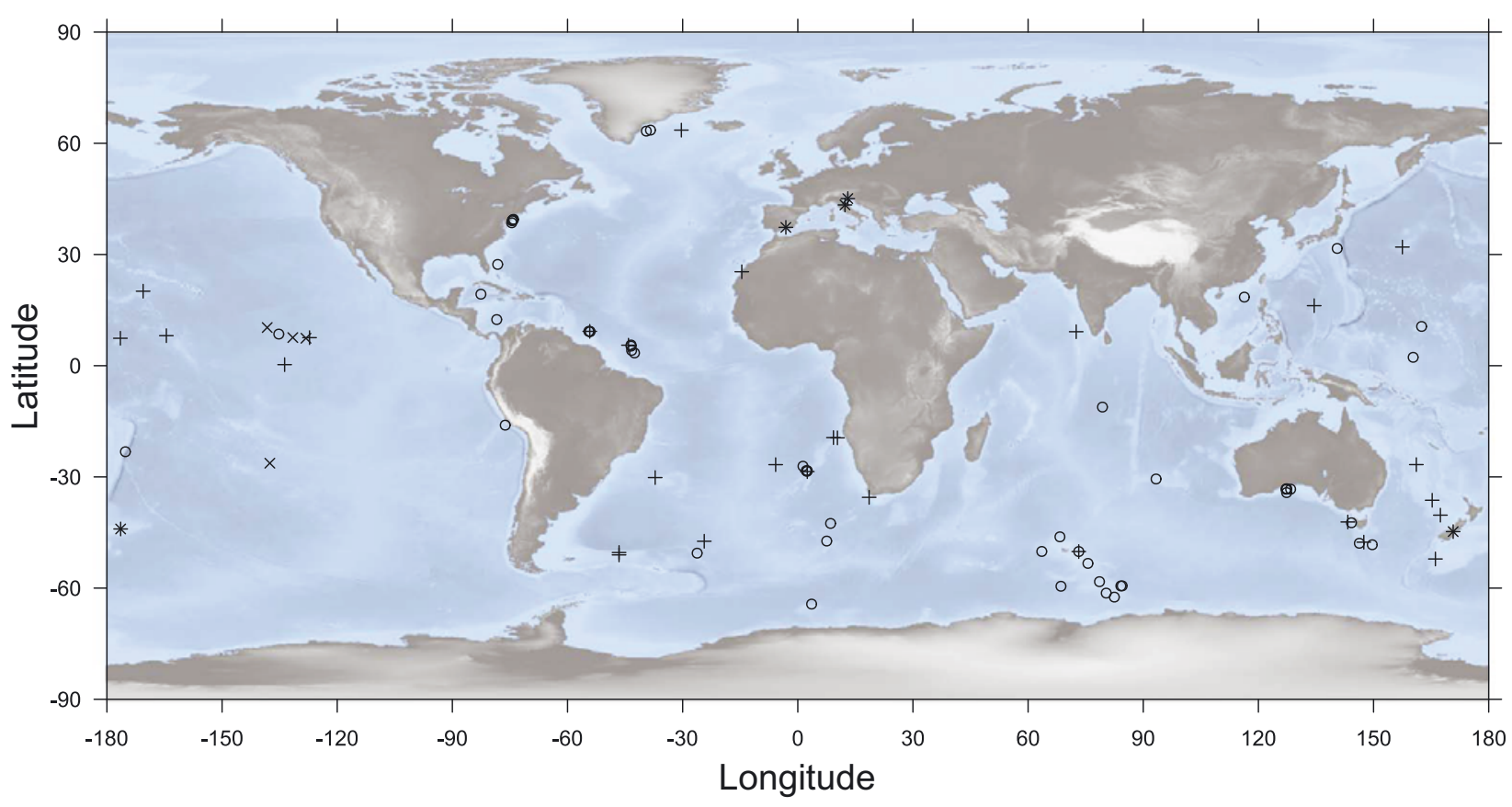

Fig. 1. Global occurrences of Chiloguembelina cubensis from the Deep Sea Drilling Program (pluses), Ocean Drilling Program (unfilled circles), Integrated Ocean Drilling Program (crosses) and other sections (stars) plotted on a bathymetric map extracted from the NOAA server at a $10 \mathrm{~m}$ resolution and plotted using the MarMap R package (version 0.9.2). 
Geographically C.cubensis is widespread and can be considered a cosmopolitan species as it has been recorded in all ocean basins ranging from $65^{\circ} \mathrm{N}$ to $65^{\circ} \mathrm{S}$ (Fig. 1). The depth habitat of C.cubensis, as inferred from stable isotope analysis, shows some degree of variability. Poore and Matthews (1984) found that specimens from the Gulf of Mexico and equatorial Atlantic Ocean indicate a shallow, mixed layer habitat, while a higher latitude South Atlantic site (Deep Sea Drilling Project Site 36) showed more intimidate values suggestive of a thermocline dwelling depth. Conversely another South Atlantic site shows values suggestive of a shallow depth habitat (Kelly et al. 2003), while Ocean Drilling Program Site 1218 in the equatorial Pacific Ocean suggested a thermocline dwelling depth habitat (Wade et al. 2007).

\section{Historical perspectives on the biostratigraphic utility of Chiloguembelina cubensis}

This review follows the chronostratigraphic framework outlined by Backman et al. (2012), where the Base (B) and Top (T) represents the lowest (first) and highest (last) taxon occurrences respectively. Top common (Tc) is used instead of the Last Common Occurrence (LCO). Where possible, the magnetic polarity Chron where the Top or Tc occurrence of C. Cubensis occurs has been given allowing for a better means of global correlation, although some sites lack adequate palaeomagnetic records and in these cases the planktonic foraminiferal biozone in which the Top or Tc occurrence of C.cubensis is used instead.

The extinction of $C$.cubensis has long been used as a bioevent for subdividing the Oligocene, with Berggren (1971), Jenkins and Orr (1972), and Berggren and Amdurer (1973) being the first studies to erect a biozone based upon the event. The bioevent became widely applied following the biochronologies of Berggren et al. $(1985,1995)$, where the Top or Tc of C.cubensis is used to subdivide Biozone P21 into subzones P21a and P21b. The zonal nomenclature of the Oligocene was updated by Berggren and Pearson (2005) to recognise "O" zones, rather than the former "P" zones. Zone $\mathrm{O} 4$ (= P21a) and O5 (= P21b) were used but retained Tc of C.cubensis to mark the early/late Oligocene boundary with magnetochron calibration towards the Top of Chron C10n.1n (Berggren and Pearson 2005, Wade et al. 2011). While earlier studies using the bio- event tended to favour the Top occurrence, meaning an abrupt/well-defined extinction, later studies increasingly favoured the use of the Tc occurrence, following the work of Huber (1991) who marked the boundary based upon the "last abundant occurrence" as opposed to the "absolute last occurrence". This was taken further by Leckie et al. (1993), who used LCO to mark the boundary, based upon C.cubensis extending into the upper Oligocene but accounting for less than $5 \%$ of the planktonic foraminiferal assemblage. Accordingly, this review follows the order of discussing sites which found a well-defined extinction, the sites which found occurrences of C.cubensis in the upper Oligocene, and how reworking may influence the stratigraphic range. Finally, alternatives to the use of C.cubensis in defining the Base of the Chattian are discussed.

\subsection{Abrupt extinction of Chiloguembelina cubensis}

A number of sites at a variety of latitudes have documented the extinction of C.cubensis as a distinct biohorizon. In the western Atlantic an abrupt termination is found on Deep Sea Drilling Project (DSDP) Leg 72 Site 516 (Rio Grande Rise, $\sim 30^{\circ} \mathrm{S}$ ), which is calibrated via palaeomagnetism to within Chron C9 (Berggren et al. 1983). The similar latitude eastern Atlantic Site 522 (Southern Angola Basin, $\sim 26^{\circ} \mathrm{S}$ ) of DSDP Leg 73 shows a distinct biohorizon within Chron C10n (Poore 1984, Poore et al. 1984), which is consistent with the Chron calibration from the higher latitude eastern Atlantic Ocean Drilling Program (ODP) Leg 114 Site 703 (Meteor Rise, $\sim 47^{\circ}$ S) (Nocchi et al. 1991, Hailwood and Clement 1991). Strontium isotope stratigraphy $\left({ }^{87} \mathrm{Sr} /{ }^{86} \mathrm{Sr}\right)$ found an age relatively consistent within the mid Oligocene in the eastern Atlantic at DSDP Leg 74 Site 529 (Walvis Ridge, $\sim 28^{\circ} \mathrm{S}$ ) (Hess et al. 1989). The discrepancies in the Chron calibration between the eastern and western Atlantic described above may reflect the poorly defined palaeomagnetics at Site 516 . Berggren et al. (1983) suggested the extinction of C.cubensis would be the most useful criterion in boundary definition for the base of the Chattian, which is reflected in Berggren et al. (1985) but chose to use Chron C10n (following Poore 1984, Poore et al. 1984) as opposed to Chron C9. In the South China Sea, an extinction is observed in Site $1148\left(\sim 18^{\circ} \mathrm{N}\right)$ of ODP Leg 184 (Li et al. 2004), which is also found in ODP Leg 182 Site 1134 (Great Australian Bight, $\sim 33^{\circ} \mathrm{S}$ ) with the two sites having a $10^{\circ}$ difference in longitude, although a hiatus is present close to the event in Site 
1134 (Li et al. 2003). At ODP Leg 199 Site 1218 $\left(\sim 8^{\circ} \mathrm{N}\right)$ the extinction is within Chron C10n.1n (Wade et al. 2007), which was used to provide the calibrated age in Wade et al. (2011).

In the equatorial Atlantic Leg 154 (Ceara Rise, 4$5^{\circ} \mathrm{N}$ ) the extinction of C.cubensis was shown to be abrupt and synchronous at four different sites (Sites 925, 926, 928 and 929) (Pearson and Chaisson 1997). This is consistent with findings from the eastern equatorial Pacific namely DSDP Leg 9 Site $77\left(\sim 0^{\circ} \mathrm{N}\right)$ which again uses ${ }^{87} \mathrm{Sr} /{ }^{86} \mathrm{Sr}$ stratigraphy and finds an age consistent with the mid Oligocene (Hess et al. 1989).

Higher latitude sites within the Southern Ocean favour the Top occurrence bioevent. Stott and Kennett (1990) erected an Antarctic biozonation scheme with the extinction of C.cubensis occurring in the mid Oligocene between AP14a/AP14b, which is equivalent to the O4/O5 (= P21a/P21b) zonal boundary of the tropical planktonic foraminiferal biochronology (Wade et al. 2011), based upon results of ODP Leg 113 Sites 689 and 690 (Maud Rise, $\sim 64-65^{\circ}$ S) correlating to the uppermost part of Subchron C10n.1n. However, a site with a similar latitude at the Kerguelen Plateau (ODP Leg 119 Site $744, \sim 61^{\circ} \mathrm{S}$ ) found the extinction in Chron C11n, although this may be due to an apparent hiatus meaning that Chron $\mathrm{C} 10 \mathrm{n}$ was uninterpretable (Huber 1991, Barron et al. 1991). Conversely abrupt extinctions were found in Sites 747 and 749 within Chron C10n, while at Site 748 the extinction occurred within the combined Chron $\mathrm{C} 9 / \mathrm{C} 10$ based on lower latitude sites of ODP Leg 120, again from Kerguelen Plateau ( 54-58 $\mathrm{S})$ (Berggren 1992). Huber and Quillévéré (2005) revised the Antarctic Paleogene planktonic foraminifera biochronology although the timing of the extinction event and Chron calibration (C10n.1n) from Stott and Kennett (1990) remained unchanged the biozone names adopted were AO2/AO3, with calibrations for the Top C.cubensis being based upon material from ODP Leg 119 Site 738 (Kerguelen Plateau, $\sim 62^{\circ} \mathrm{S}$ ). While the authors used and found the "Last Appearance Datum" (= Top) to mark the lower/upper Oligocene boundary, they preferred the use of Tc due to occurrences in the upper Oligocene outside of the studied sites.

\subsection{Extended range of Chiloguembelina cubensis}

Despite the evidence for an abrupt extinction of $C$. $\mathrm{Cu}$ bensis, a number of other study sites have shown an extended range of $C$.cubensis into the late Oligocene. A large proportion of the sites which find late Oligocene occurrences of $C$.cubensis are in the south west Pacific and Austral Realm. Jenkins and Srinivasan (1986), focused predominantly on DSDP Leg 90 Site 588 (Lord Howe Rise, $\sim 26^{\circ} \mathrm{S}$ ) and Site 593 (Challenger Plateau, $\sim 40^{\circ} \mathrm{S}$ ) but also examined the extinction level from other nearby Pacific Ocean sites, namely DSDP Leg 29 Site 277 (South Campbell Plateau, $\sim 52^{\circ} \mathrm{S}$ ) and Site 282 (Tasmania, $\sim 42^{\circ} \mathrm{S}$ ) effectively creating a transect from the equatorial to sub-Antarctic regions. The authors did not opt for using the biozones suggested in Berggren et al. (1985) (P21a/P21b) and instead used the extinction of 'Globigerina' angiporoides as a means to differentiate between the early and late Oligocene. In all the aforementioned sites, C.cubensis was suggested to range into the late Oligocene and was subsequently used as a bioevent in the biozone scheme for the subtropical realm in this study. The findings from Site 593 agree with Hess et al. (1989) who suggested a range towards the basal Miocene based upon ${ }^{87} \mathrm{Sr} /{ }^{86} \mathrm{Sr}$ stratigraphy at the same site. Hornibrook (1990) studied land based sections in New Zealand from a similar latitude to Site 282 and found an extended range into the late Oligocene and early Miocene in the Waitaki Valley $\left(\sim 44^{\circ} \mathrm{S}\right)$ and Chatham Islands $\left(\sim 43^{\circ} \mathrm{S}\right)$ respectively based upon calibration to the New Zealand planktonic foraminiferal biozones of Jenkins (1966). ODP Leg 189 Site 1168 (western Tasmanian Margin, $\sim 42^{\circ} \mathrm{S}$ ) was located $80 \mathrm{~km}$ south of Site 282 and C.cubensis was found to range into the upper Oligocene within Chron C9r, although unlike Site 282 the Tc occurrence of C.cubensis was used as a bioevent, although this data was based solely on shipboard core catcher samples at a low resolution, so further analysis to improve the biostratigraphic resolution would help to aid the timing of the extinction (Stickley et al. 2004).

In the equatorial Pacific a number of sites showed an extended range. As previously mentioned, Leckie et al. (1993) used the Tc occurrence of C.cubensis to mark the base of Biozone P21b on ODP Leg 130 Site 803 (Ontong Java Plateau, $\sim 2^{\circ} \mathrm{N}$ ) in the western Pacific and found the species to be a persistent, but rare component, of the planktonic foraminiferal assemblages up until Chron C7n (Biozone P22). In the eastern equatorial Pacific DSDP Leg 9 Site $77\left(\sim 0^{\circ} \mathrm{N}\right)$ and Site 79 $\left(\sim 7^{\circ} \mathrm{N}\right)$, the authors suggested $C$. cubensis ranged into the late Oligocene and used the species as a marker across the Leg 9 sites, although no palaeomagnetics are available for these two sites (Jenkins and Orr 1972). 
Site U1336 $\left(\sim 7^{\circ} \mathrm{N}\right)$ also used the Tc C. cubensis occurrence to mark the base of Biozone O5, although the range charts at this site do not list any occurrences above Biozone O4 (Expedition 320/321 Scientists 2010b), while other sites of the eastern equatorial Pacific (DSDP Leg 34 Sites 320 and $321,9^{\circ} \mathrm{S}$ and $12^{\circ} \mathrm{S}$ ) found a range to the early Miocene (Quilty 1976).

Comparable latitude sites in the North and South Atlantic found ranges extending into late Oligocene. Jenkins and Srinivasan (1986) examined the south east Atlantic Site $360\left(\sim 35^{\circ} \mathrm{S}\right)$ of DSDP Leg 40, in addition to the Pacific sites previously discussed, and found the level to be consistent with the other sites analysed as part of the study. Similarly, at ODP Leg 101 Site $628\left(\sim 27^{\circ} \mathrm{N}\right)$ the range of C.cubensis is extended slightly beyond the level recorded at Site 803, although the site lacked palaeomagnetic calibration but again $C$.cubensis was found to be rare in the upper Oligocene so the Tc occurrence was used to mark the base of Biozone P21b (Leckie et al. 1993). In a number of European sections, Tc C.cubensis was used to define the base of Biozone O5. The Fuente Caldera in Southern Spain $\left(\sim 37^{\circ} \mathrm{N}\right)$ has a relatively continuous record of $C$.cubensis with peak abundances occurring in Biozone O2, while the base of Biozone O5 being tentatively placed between the Tc and Top occurrence of C.cubensis (Alegret et al. 2008). In the Northern Adriatic Sea $\left(\sim 45^{\circ} \mathrm{N}\right)$ C.cubensis is shown to have a range into the upper Oligocene, although the occurrences in Biozone O5 are generally less than 5\%, therefore the lower/upper Oligocene boundary here is marked by the Tc of $C$.cubensis (Hernitz-Kučenjak et al. 2014). This is consistent with the similar latitude site in the Umbria Marche Basin $\left(\sim 43^{\circ} \mathrm{N}\right)$ in Central Italy, with three sites finding the Tc C.cubensis occurrence within the upper part of Chron C10n. The Tc occurrence of C.cubensis at this locality is the current correlation event for defining the GSSP for the base of the Chattian, with the favoured section being the Monte Cagnero section (Coccioni et al. 2008, 2013).

\subsection{Reworking}

As C.cubensis is a small planktonic foraminifera species, it is relatively susceptible to sediment reworking (e.g. Poore et al. 1984, Pearson 1995, Wade et al. 2007). Detecting such a process is important in order not to give a false stratigraphic range. For example, a number of authors have directly attributed reworking to younger occurrences of C.cubensis including at DSDP Leg 9 Sites 77 and 79 (Jenkins and Orr 1972),
DSDP Leg 73 Site 522 (Poore 1984), ODP Leg 119 Site 744 (Huber 1991) and ODP Leg 126 Site 793 (Herman 1992). Conversely, Hornibrook (1990) discounted reworking of C.cubensis on Chatham Island due to limited outcrops of Oligocene age and the delicate nature of the specimens. Some sites do not discuss reworking and rather directly attribute the occurrence as representing a true stratigraphic range. For example, DSDP Leg 34 suggests a range into the early Miocene, despite only a single specimen of $C$. cubensis being present within one Miocene aged sample at Site 320, and while Site 321 shows a more continuous stratigraphic range that is restricted to the Oligocene, the age is unclear due to difficulties in biozone correlation (Quilty 1976).

It is worth noting that all of the studies discussed in this section predate Leckie et al. (1993) and Berggren et al. (1995) where Tc became the favourable bioevent. However, due to the limited availability of abundance counts (relative or absolute), it is difficult to assess whether the Tc occurrence of $C$.cubensis could have been applied at these sites, instead of solely a Top occurrence with all younger occurrences being linked to sediment reworking.

\subsection{Other potential markers for the base of the Chattian}

Van Simaeys et al. (2004) argued that the extinction of C.cubensis is diachronous and latitudinally controlled, so cannot be considered a suitable marker for GSSP assignment. Instead the best marker for the boundary in the southern North Sea basin is a decrease in benthic foraminiferal diversity and bloom in the abundance of the benthic foraminifera Asterigerinoides guerichi. The authors state that while the latter of these events is correlatable through the North Sea basin, the species is endemic to this region, so based upon the criteria for GSSP definition set out by Remane et al. (1996) this bioevent is not widely correlatable outside of this region, so is an unsuitable bioevent for GSSP definition. Other markers listed as potential correlation events in the Umbra Marche Basin include the Tc of the calcareous nannofossil species Sphenolithus distentus, the abundance interval of the dinoflagellate genus Svalbardella or the oxygen isotope increase (Oi-2a), with the latter of these having preference due to the potential for global correlation (Coccioni et al. 2008). Oi-2a represents a short lived (70-130 kyr) positive oxygen isotope excursion seen in both planktonic and benthic foraminiferal records, modulated by eccentricity and obliquity cycles, leading to Antarctic ice sheet expan- 
sion and a decline in global sea levels (Wade and Pälike 2004).

\section{Study sites and methods}

\subsection{Study sites}

Ocean Drilling Program Leg 202, Site 1237 was drilled in the southeast Pacific Ocean $\left(16^{\circ} 0.421^{\prime} \mathrm{S}, 76^{\circ} 22\right.$. $680^{\prime} \mathrm{W}$ ) in $3217 \mathrm{~m}$ water depth. Hole 1237B recovered a $55.2 \mathrm{~m}$ near complete Oligocene, characterised primarily by pelagic sedimentation of nannofossil ooze with a sedimentation rate between $8-10 \mathrm{~m} / \mathrm{my}$ (Shipboard Scientific Party 2003), although a revised agedepth model is presented in this study.

Integrated Ocean Drilling Program Expedition 320 Hole U1334A (4790 m water depth) is located in the eastern equatorial Pacific Ocean $\left(7^{\circ} 59.998^{\prime} \mathrm{N}, 131^{\circ}\right.$ $58.394^{\prime} \mathrm{W}$ ) and contains a complete Oligocene between cores $11 \mathrm{H}$ to $26 \mathrm{X}$. Like Site 1237 , the site is characterised by pelagic nannofossil ooze, although the sedi- mentation rate is considerably higher at an average of $24 \mathrm{~m} / \mathrm{my}$ in the lower Oligocene, decreasing to $14 \mathrm{~m} /$ my in the upper Oligocene (Expedition 320/321 Scientists 2010a).

When the two sites are backtracked it can be seen that Site 1237 was located in an open ocean setting compared to the current day locality (Fig. 2) at a palaeolatitude of approximately $19^{\circ} \mathrm{S}$ in the mid Oligocene within an oligotrophic gyre (Shipboard Scientific Party 2003). Conversely, Site U1334 was located in an area of complex oceanography within the equatorial upwelling zone, meaning productivity was likely higher relative to other areas of the Oligocene ocean (Expedition 320/321 Scientists 2010a). The backtrack of Site U1334 (Fig. 2), indicates a palaeolatitude of approximately $2^{\circ} \mathrm{N}$ in the mid Oligocene (Pälike et al. 2012).

\subsection{Materials}

From Hole 1237B, we examined 36 samples from core sections $30 \mathrm{H}-1$ to $34 \mathrm{H}-5$, equivalent to 272.35 to 316.37 metres below sea floor (mbsf) or 305.96

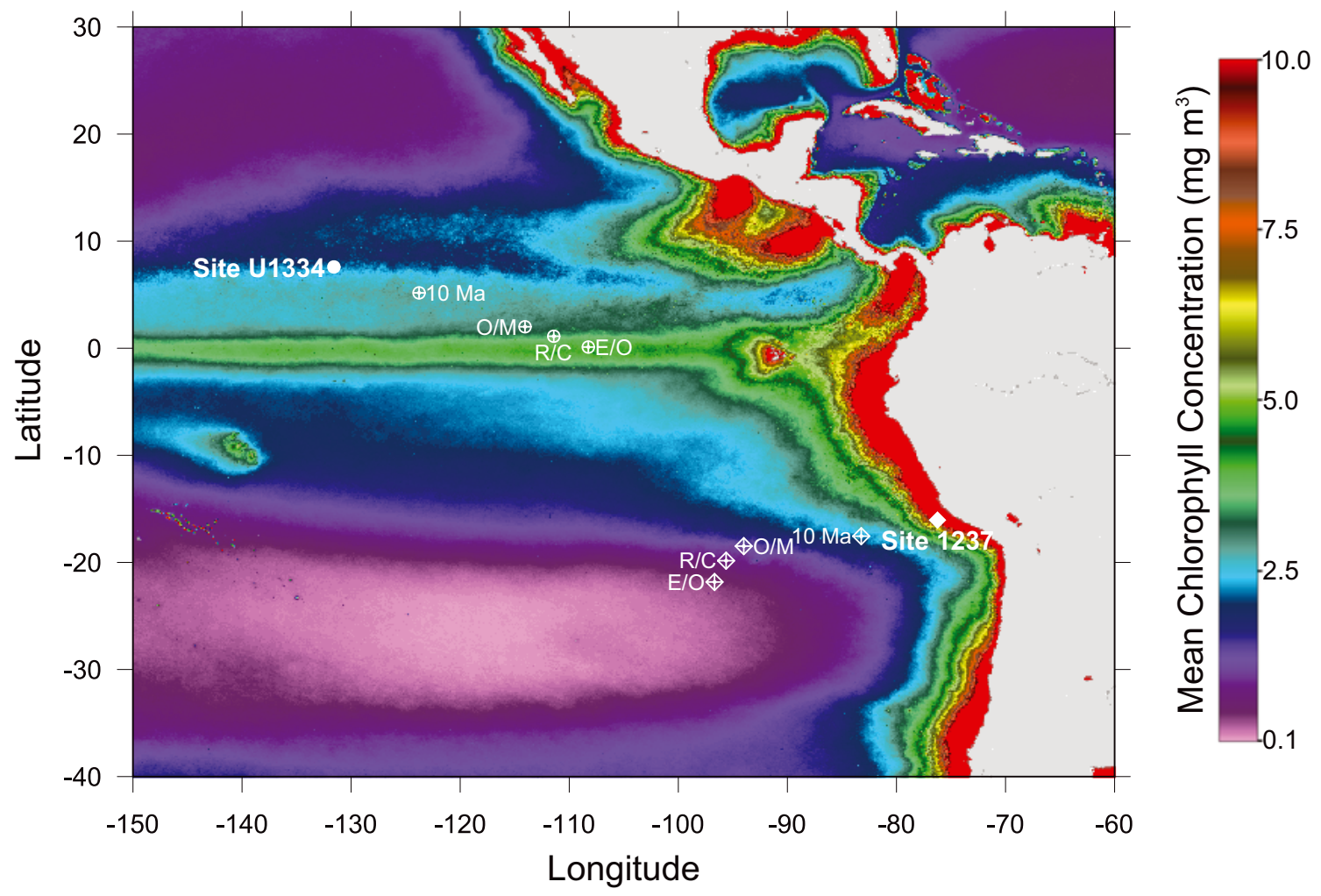

Fig. 2. Cumulative average sea-surface chlorophyll concentrations $\left(\mathrm{mg} \mathrm{m}^{3}\right)$ of the eastern Pacific Ocean for the period September 1997 to November 2010 derived from the SeaWiFS satellite (http://oceancolor.gsfc.nasa.gov/). The unfilled circle and diamond points show the backtracked positions for Site U1334 (Pälike et al. 2012) and Site 1237 (Shipboard Scientific Party 2002) respectively across the Eocene-Oligocene (E/O), Rupelian-Chattian (R/C), Oligocene-Miocene (O/M) and at $10 \mathrm{Ma}$. The filled points show the present day positions of Site U1334 and Site 1237. 
to 357.48 metres composite depth (mcd), covering $\sim 24.2 \mathrm{Ma}$ to $\sim 32 \mathrm{Ma}$. To accurately quantify the biostratigraphic changes and, ultimately the extinction level of C.cubensis, the samples between $31 \mathrm{H}-3$ to 32H-4 (284.9-296.4 mbsf) were studied every $50 \mathrm{~cm}$ and increased to $3 \mathrm{~cm}$ resolution between $31 \mathrm{H}-7$ to $32 \mathrm{H}-1$. The samples above $31 \mathrm{H}-3$ and below $32 \mathrm{H}-4$ are at a $3 \mathrm{~m}$ resolution.

From Hole U1334A, 38 samples were studied, corresponding to 141.64 to 198.14 metres core depth below seafloor (m CSF) and equivalent to 162.39 to 239.38 m CCSF-A (metres composite core depth below sea floor) from Westerhold et al. (2012). The core sections covered $16 \mathrm{H}-1$ to $21 \mathrm{H}-7$, spanning Chron C9n to Chron C11n.2n, equivalent to $\sim 26.7 \mathrm{Ma}$ to $\sim 30.5 \mathrm{Ma}$. The data was plotted relative to the depth scale of Westerhold et al. (2012), using the available composite shipboard magnetostratigraphy for all three drilled holes at Site U1334 (Expedition 320/321 Scientists 2010a).

\subsection{Abundance counts}

Samples were wet sieved through a $63 \mu \mathrm{m}$ mesh and the 63-150 $\mu \mathrm{m}$ size fraction was examined using a binocular light microscope. For the relative abundance counts a total of 300 planktonic foraminifera specimens were counted with the number of biserial planktonic forms (C.cubensis) recorded relative to the number of nonbiserial planktonic forms. The dominance of radiolarians within the Hole U1334A samples meant relative abundance counts were not possible for the samples in which planktonic foraminifera constituted a low percentage of the entire microfossil assemblage. In order to account for this, absolute abundances were applied for all samples from Hole U1334A and took into account the number of biserial planktonic forms for a single picking tray. In each case a similar amount of sediment was spread across the tray in order to eliminate bias.

\subsection{Scanning Electron Microscope imaging}

Twenty-three and twenty-five specimens were imaged using the scanning electron microscope from Holes 1237B and U1334A respectively. These specimens were mounted on a $10 \mathrm{~mm}$ SEM stub, before being coated in gold-palladium using a Gatan ion beam coater. They were imaged using a JEOL JSM-7401F scanning electron microscope at University College London. SEM imaging allowed for clearer distinction between the biserial species, which relied primarily on the taxonomic concepts presented in Huber et al. (2006).

\subsection{Morphometric analysis}

For Hole 1237B and Hole U1334A, morphometric analysis was conducted on 59 and 69 specimens respectively. The selected specimens were mounted on a picking tray in lateral view and measured using an Olympus S2X7 microscope and Image-Pro Premier Computer Software. For each specimen the maximum test length was measured automatically, while the maximum test width was measured manually.

\subsection{Magnetostratigraphic record and updated age-depth model for Site 1237}

As part of this study, we constructed the lower Oligocene palaeomagnetic record at Site 1237 as this data was not interpreted by the Shipboard Scientific Party (2003). The available data was downloaded from the Ocean Drilling Program database (http://www-odp. tamu.edu/database/) with both the inclination and declination data being considered. The record was analysed between 255.01 to 319.19 mbsf and consisted of 3946 data points. In order to better identify normal and reverse polarities a five period moving average was fitted to both datasets.

To provide age control points for Chron interpretation, an Oligocene age-depth model was plotted which took into account levels from a revised biostratigraphy (this study), Shipboard Scientific Party (2003), and Flower and Chisholm (2006). This allowed for the definition of biozones, with the Top or Base of key index planktonic foraminifera fossils providing a core level for the bioevents, which in turn acted as a means for calibrating the magnetic polarity chrons. The calibration ages for the planktonic foraminifera came from Wade et al. (2011) and the ages for the Chron boundaries are from Pälike et al. (2006). The age-depth model allowed a reassessment of the sedimentation rate for the Oligocene and lower Miocene to be made.

\section{Results}

\subsection{Oligocene magnetostratigraphy for Site 1237}

To accurately assess the timing of the extinction of C.cubensis at Site 1237, a re-examination of the magento- and biostratigraphy was required. The shipboard palaeomagnetic record for the interval from 290 to 319 mbsf was not interpreted during the expedition, so 
we have reassessed the magnetostratigraphy with new and revised planktonic foraminifera biostratigraphy. A near complete Oligocene and basal Miocene sequence has been inferred from the available palaeomagnetic and biostratigraphic data (Figs.3, 4; Table 1). The Chron interpretations were based primarily on the declination data as this showed a clearer degree of variance between normal and reversed polarities, with the inclination data acting as a secondary means to evaluate Chron assignment (Fig. 3).
Our upper Oligocene magnetostratigraphic interpretation is broadly similar to the findings of the Shipboard Scientific Party (2003) and Flower and Chisholm (2006). The record spans Subchron C10n.1n at 290.85 mbsf to Chron C6Cn.2n at the Oligocene/ Miocene boundary in core 29H-4 (Fig. 3). The base of Biozone $\mathrm{O} 5$ is determined by the Top occurrence of C.cubensis between samples $31 \mathrm{H}-7,75-77 \mathrm{~cm}$ and $32 \mathrm{H}-1,35-37 \mathrm{~cm}$, at $290.84 \pm 0.02 \mathrm{mbsf}$, within Subchron C10n.1n. Between 292.8 mbsf (32H-2) to

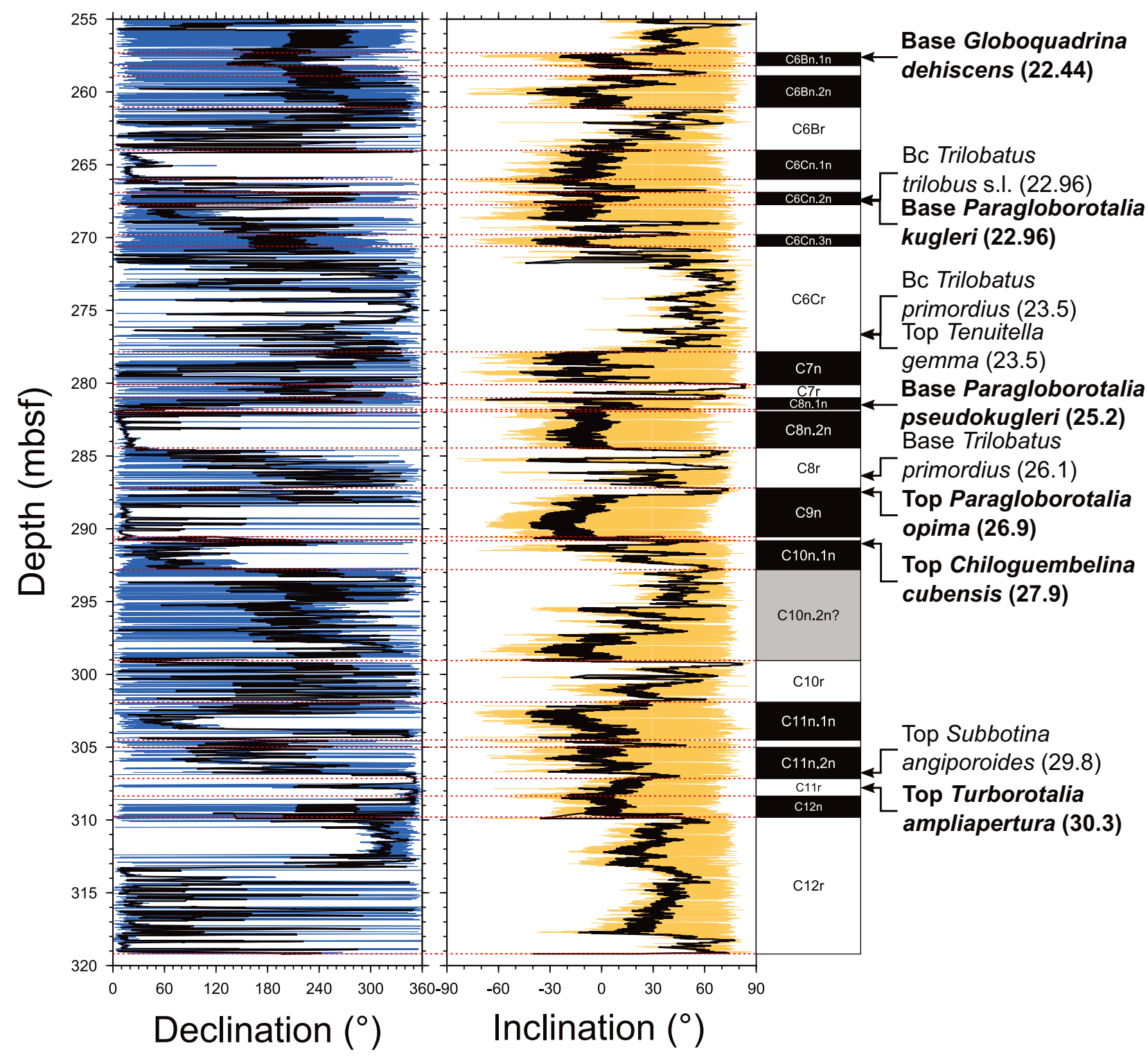

Fig. 3. Palaeomagnetic interpretation for Site 1237 based upon the available inclination and declination data from the Shipboard palaeomagnetics survey (http://www-odp.tamu.edu/database/) and biostratigraphy (Shipboard Scientific Party 2003, Flower and Crisholm 2006 and this study). The ages of the biostratigraphic datums come from Wade et al. (2011), except C.cubensis which is from this study. Oligocene ages are calibrated to the astronomical timescale of Pälike et al. (2006), while Miocene ages are calibrated to the astronomical timescale of Lourens et al. (2004). Primary marker species are in bold. 


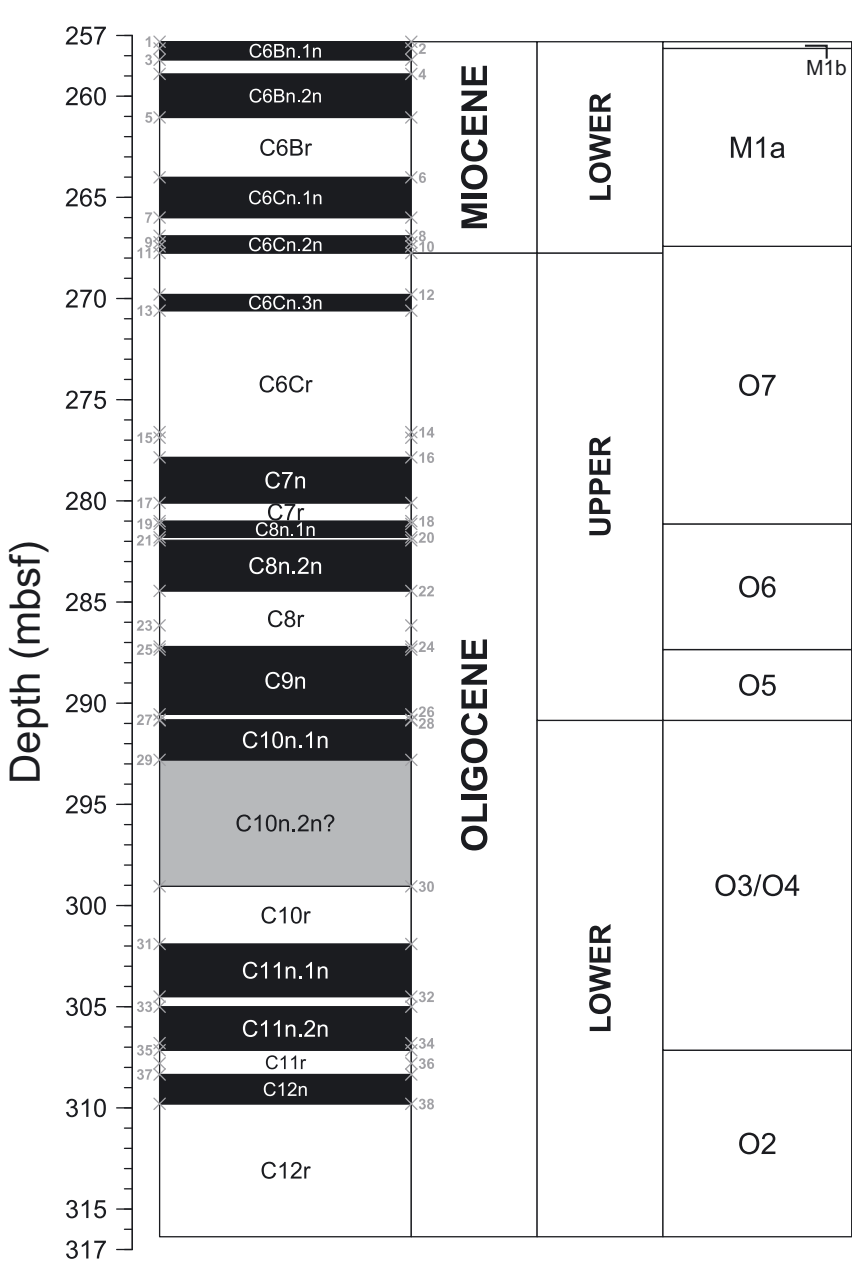

Fig. 4. Magnetostratigraphic record for Site 1237 as inferred from data from the Janus Web Database (http://www. odp.tamu.edu/database/). The numbered grey crosses refer to the age-depth tie points shown in Table 1.

299.05 mbsf (32H-6) the magnetostratigraphy has not been interpreted. This contains the Subchron C10n.2n and subsequent short-term reversal (C10n.1r), but there are no clear changes in the inclination or declination data and so no interpretation can be made.

One drawback with the biostratigraphy from Shipboard Scientific Party (2003), is the $9 \mathrm{~m}$ resolution of the core catcher samples creating a large degree of error in the depth of the Top or Base of the index fossils from this site. However, in order to reduce this error both biostratigraphic and magnetostratigraphic datums have been used to calibrate the depths but this still remains problematic for the Base of 'Globigerina' angulisuturalis, which is the marker for the base of the Zone O4 within Chron C11n.1n (Wade et al. 2011). The base of 'Globigerina' angulisuturalis at Hole 1237B could not be resolved and therefore Zones O3 and $\mathrm{O} 4$ are undifferentiated. A higher resolution study on the Oligocene assemblages of planktonic foraminifera at this site would provide a better means of calibration in resolving the polarity Chrons and planktonic foraminiferal biozones.

\subsection{Chiloguembelina cubensis abundance and biostratigraphic implications}

\subsubsection{Hole 1237B}

Planktonic foraminifera are the dominant microfossil component throughout all the samples at Site 1237, allowing for a precise means to characterise the abundance changes in C.cubensis (Fig.5; Table 2). The three basal samples, between 310.35 to $316.37 \mathrm{mbsf}$ (34H-1 to $34 \mathrm{H}-5)$, marks the period of peak abundance in biserial forms which ranges from $8.67-14 \%$ of the total assemblage. The low abundance seen in core section $33 \mathrm{H}-5$ (306.88 mbsf) can be attributed to the anomalousness of the sample, which falls in a band of

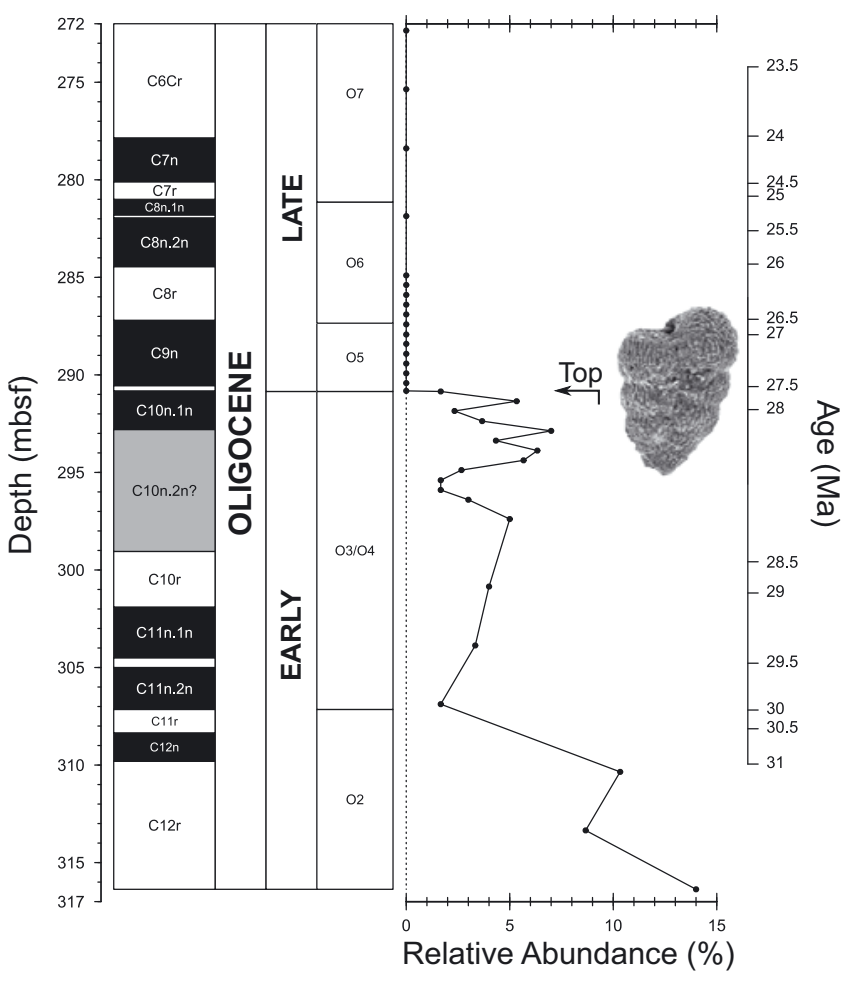

Fig. 5. Relative abundance changes for biserial planktonic foraminifera at Site 1237 between 272-316 metres below sea floor (mbsf), plotted against the magnetostratigraphy presented in Fig. 3 and the astronomical timescale of Pälike et al. (2006). The arrow designates the Top occurrence of C.cubensis at this site. 
Table 1 Age-depth tie points used in the construction of the magnetostratigraphic record for Hole 1237B (Fig. 4). The Fig 4 tie points relate to the numbered crossed in Fig. 4. Biostratigraphic datum depths are from Shipboard Scientific Party (2003), except Top Tenuitella gemma and Chiloguembelina cubensis (this study) and Paragloborotalia opi$m a$ (Flower and Crisholm 2006). Biostratigraphic datum calibrations are from Wade et al. (2011), except C.cubensis (this study, see Table 4 for calibration details). Oligocene ages are calibrated to the astronomical timescale of Pälike et al. (2006), while Miocene ages are calibrated to the astronomical timescale of Lourens et al. (2004). Planktonic foraminifera bioevents are to two decimal places in the Neogene and one decimal place in the Palaeogene.

\begin{tabular}{|c|c|c|c|}
\hline Fig. 4 Tie Point & Marker & Age (Ma) & Mean Depth (mbsf) \\
\hline 1 & Top C6Bn.1n & 21.767 & 257.31 \\
\hline 2 & Base Globoquadrina dehiscens & 22.44 & 257.64 \\
\hline 3 & Base C6Bn.1n & 21.936 & 258.20 \\
\hline 4 & Top C6Bn.2n & 21.992 & 258.90 \\
\hline 5 & Base C6Bn.2n & 22.268 & 261.05 \\
\hline 6 & Top C6Cn.1n & 22.564 & 264.01 \\
\hline 7 & Base C6Cn.1n & 22.754 & 266.00 \\
\hline 8 & Top C6Cn.2n & 22.902 & 266.90 \\
\hline 9 & Base Trilobatus trilobus sensu lato & 22.96 & 267.22 \\
\hline 10 & Base Paragloborotalia kugleri & 22.96 & 267.42 \\
\hline 11 & Base C6Cn.2n & 23.03 & 267.75 \\
\hline 12 & Top C6Cn.3n & 23.278 & 269.80 \\
\hline 13 & Base C6Cn.3n & 23.34 & 270.60 \\
\hline 14 & Bc Trilobatus primordius & 23.5 & 276.60 \\
\hline 15 & Top Tenuitella gemma & 23.5 & 276.88 \\
\hline 16 & Top C7n & 24.022 & 277.85 \\
\hline 17 & Base C7n & 24.459 & 280.10 \\
\hline 18 & Top C8n.1n & 25.11 & 281.00 \\
\hline 19 & Base Paragloborotalia pseudokugleri & 25.2 & 281.14 \\
\hline 20 & Base C8n.1n & 25.248 & 281.80 \\
\hline 21 & Top C8n.2n & 25.306 & 281.95 \\
\hline 22 & Base C $8 n .2 n$ & 26.032 & 284.45 \\
\hline 23 & Base Trilobatus primordius & 26.1 & 286.16 \\
\hline 24 & Top C9n & 26.508 & 287.20 \\
\hline 25 & Top Paragloborotalia opima & 26.9 & 287.35 \\
\hline 26 & Base C9n & 27.412 & 290.55 \\
\hline 27 & Top C10n.1n & 27.886 & 290.82 \\
\hline 28 & Top Chiloguembelina cubensis & 27.888 & 290.85 \\
\hline 29 & Base C10n.1n & 28.126 & 292.80 \\
\hline 30 & Base C10n.2n & 28.318 & 299.05 \\
\hline 31 & Top C11n.1n & 29.166 & 301.90 \\
\hline 32 & Base C11n.1n & 29.467 & 304.50 \\
\hline 33 & Top C11n.2n & 29.536 & 305.00 \\
\hline 34 & Top Subbotina angiporoides & 29.8 & 306.80 \\
\hline 35 & Base C11n.2n & 29.957 & 307.15 \\
\hline 36 & Top Turborotalia ampliapertura & 30.3 & 307.80 \\
\hline 37 & Top $\mathrm{C} 12 \mathrm{n}$ & 30.617 & 308.35 \\
\hline 38 & Base $\mathrm{C} 12 \mathrm{n}$ & 30.977 & 309.80 \\
\hline
\end{tabular}


Table 2 Relative abundance data for Hole 1237B showing samples, depths, ages and the inferred Chron and biozone for each sample.

\begin{tabular}{|c|c|c|c|c|c|c|c|c|c|}
\hline Core & Section & $\begin{array}{c}\text { Top } \\
\text { Interval } \\
\text { (cm) } \\
\end{array}$ & $\begin{array}{c}\text { Bottom } \\
\text { Interval } \\
\text { (cm) }\end{array}$ & $\begin{array}{l}\text { Depth } \\
\text { (mbsf) }\end{array}$ & $\begin{array}{l}\text { Depth } \\
\text { (mcd) }\end{array}$ & $\begin{array}{l}\text { Age } \\
\text { (Ma) }\end{array}$ & $\begin{array}{c}\text { Relative } \\
\text { Abundance } \\
(\%)\end{array}$ & $\begin{array}{l}\text { Sample } \\
\text { Chron }\end{array}$ & $\begin{array}{l}\text { Sample } \\
\text { Biozone }\end{array}$ \\
\hline \multirow{3}{*}{$30 \mathrm{H}$} & 1 & 85 & 87 & 272.35 & 305.96 & 23.50 & 0.00 & \multirow{2}{*}{$\mathrm{C} 6 \mathrm{Cr}$} & \multirow{3}{*}{ O7 } \\
\hline & 3 & 85 & 87 & 275.36 & 308.97 & 23.79 & 0.00 & & \\
\hline & 5 & 85 & 87 & 278.39 & 312.00 & 24.13 & 0.00 & $\mathrm{C} 7 \mathrm{n}$ & \\
\hline \multirow{14}{*}{$31 \mathrm{H}$} & 1 & 86 & 88 & 281.87 & 317.28 & 25.25 & 0.00 & C8n.1r & \multirow{7}{*}{ O6 } \\
\hline & 3 & 86 & 88 & 284.91 & 320.32 & 26.05 & 0.00 & \multirow{5}{*}{$\mathrm{C} 8 \mathrm{r}$} & \\
\hline & 3 & 135 & 137 & 285.39 & 320.80 & 26.07 & 0.00 & & \\
\hline & 4 & 35 & 37 & 285.90 & 321.31 & 26.09 & 0.00 & & \\
\hline & 4 & 85 & 87 & 286.40 & 321.81 & 26.19 & 0.00 & & \\
\hline & 4 & 135 & 137 & 286.90 & 322.31 & 26.38 & 0.00 & & \\
\hline & 5 & 35 & 37 & 287.41 & 322.82 & 26.92 & 0.00 & \multirow{7}{*}{ C9n } & \\
\hline & 5 & 87 & 89 & 287.95 & 323.36 & 27.00 & 0.00 & & \multirow{7}{*}{ O5 } \\
\hline & 5 & 135 & 137 & 288.41 & 323.82 & 27.08 & 0.00 & & \\
\hline & 6 & 36 & 38 & 288.92 & 324.33 & 27.16 & 0.00 & & \\
\hline & 6 & 85 & 87 & 289.42 & 324.83 & 27.23 & 0.00 & & \\
\hline & 6 & 135 & 137 & 289.92 & 325.33 & 27.32 & 0.00 & & \\
\hline & 7 & 35 & 37 & 290.42 & 325.83 & 27.40 & 0.00 & & \\
\hline & 7 & 75 & 77 & 290.82 & 326.23 & 27.88 & 0.00 & \multirow{5}{*}{ C10n.1n } & \\
\hline \multirow{13}{*}{$32 \mathrm{H}$} & 1 & 35 & 37 & 290.85 & 328.66 & 27.89 & 1.67 & & \multirow{16}{*}{$\mathrm{O} 3 / \mathrm{O} 4$} \\
\hline & 1 & 85 & 87 & 291.35 & 329.16 & 27.95 & 5.33 & & \\
\hline & 1 & 135 & 137 & 291.85 & 329.66 & 28.01 & 2.33 & & \\
\hline & 2 & 35 & 37 & 292.37 & 330.18 & 28.07 & 3.67 & & \\
\hline & 2 & 85 & 87 & 292.87 & 330.68 & 28.13 & 7.00 & \multirow{9}{*}{ C10n. 2 n? } & \\
\hline & 2 & 135 & 137 & 293.37 & 331.18 & 28.15 & 4.33 & & \\
\hline & 3 & 35 & 37 & 293.88 & 331.69 & 28.19 & 6.33 & & \\
\hline & 3 & 85 & 87 & 294.38 & 332.19 & 28.20 & 5.67 & & \\
\hline & 3 & 135 & 137 & 294.88 & 332.69 & 28.22 & 2.67 & & \\
\hline & 4 & 35 & 37 & 295.40 & 333.21 & 28.23 & 1.67 & & \\
\hline & 4 & 85 & 87 & 295.90 & 333.71 & 28.25 & 1.67 & & \\
\hline & 4 & 135 & 137 & 296.40 & 334.21 & 28.26 & 3.00 & & \\
\hline & 5 & 85 & 87 & 297.39 & 335.20 & 28.28 & 5.00 & & \\
\hline \multirow{3}{*}{$33 \mathrm{H}$} & 1 & 85 & 87 & 300.85 & 340.71 & 28.86 & 4.00 & $\mathrm{C} 10 \mathrm{r}$ & \\
\hline & 3 & 85 & 87 & 303.87 & 343.73 & 29.40 & 3.33 & C11n.1n & \\
\hline & 5 & 85 & 87 & 306.88 & 346.74 & 29.80 & 1.67 & C11n.2n & \\
\hline \multirow{3}{*}{$34 \mathrm{H}$} & 1 & 85 & 87 & 310.35 & 351.46 & N/A & 10.33 & \multirow{3}{*}{$\mathrm{C} 12 \mathrm{r}$} & \multirow{3}{*}{$\mathrm{O} 2$} \\
\hline & 3 & 85 & 87 & 313.35 & 354.46 & N/A & 8.67 & & \\
\hline & 5 & 85 & 87 & 316.37 & 357.48 & N/A & 14.00 & & \\
\hline
\end{tabular}

partially lithified mudstone (Shipboard Scientific Party 2003) meaning planktonic foraminifera occurred in a much lower abundance compared to the other studied samples. Throughout the rest of the measured interval in which C.cubensis is present, the relative abundance remains fairly low fluctuating between $1.67 \%$ and $5 \%$, with a peak of $7 \%$ at $292.87 \mathrm{mbsf}$ $(32 \mathrm{H}-2)$. At $291.35 \mathrm{mbsf}$, there is the minor peak of $5.33 \%$ before declining to $1.67 \%$ at $290.85 \mathrm{mbsf}$, correlating to the very top of Subchron C10n.1n within core section 32H-1. Upcore from $290.82 \mathrm{mbsf}$ (31H-7) there are no occurrences of $C$. cubensis in the analysed samples, which remains the case until the last measured sample at a depth of $272.35 \mathrm{mbsf}$. The Top occurrence of C.cubensis in Hole 1237B (Table 2) in constrained within a $3 \mathrm{~cm}$ interval, in which the base of Zone O5 is placed at $290.84 \pm 0.02 \mathrm{mbsf}$.

\subsubsection{Hole U1334A}

Site U1334 was extremely rich in radiolarians, so the abundance of planktonic foraminifera in each sample was controlled by the dominance of radiolarians mean- 


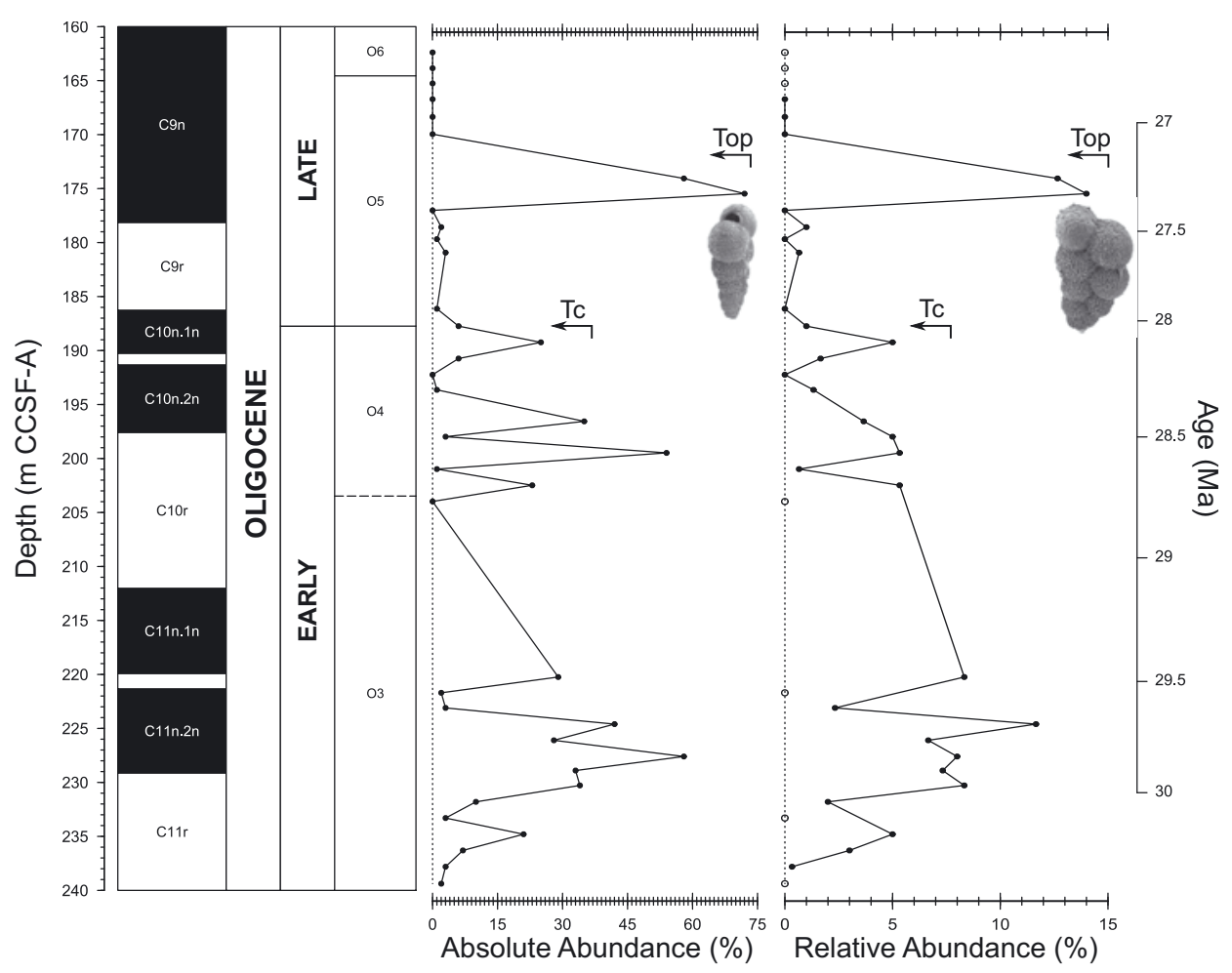

Fig. 6. Absolute and relative abundance changes for biserial planktonic foraminifera at Site U1334 between $162-239$ metres composite core depth below sea floor (m CCSF-A) of Westerhold et al. (2012). The palaeomagnetic and biozone data come from the initial shipboard report (Expedition 320/321 Scientists 2010a), except for the Base of Zone O6 which is based on Wade et al. (2016). All data has been calibrated to the astronomical chronology of Pälike et al. (2006). The arrow designates the Top and Top Common (Tc) occurrence of C.cubensis at this site.

ing the absolute and relative abundance records of C.cubensis were erratic (Fig.6; Table 3). However, the two records mirror one another relatively well with only a few discrepancies existing, providing confidence in our data.

The basal samples, between core sections $21 \mathrm{H}-2$ to $21 \mathrm{H}-7$, equivalent to 231.8 to $239.38 \mathrm{~m}$ CCSF-A have relatively low abundances before a period of marked increase between cores $20 \mathrm{H}-4$ to $21 \mathrm{H}-1$ (224.60 to $230.28 \mathrm{~m}$ CCSF-A). Between $224.60 \mathrm{~m}$ CCSF-A and up until the inferred base of Zone O5 at $187.74 \mathrm{~m}$ CCSF-A there are abrupt fluctuations in the abundance of C.cubensis in which the peaks range from 29 54 specimens, which are separated by one to two samples with low abundances.

Between $17 \mathrm{H}-3$ to $18 \mathrm{H}-3$ (177.02-187.74 m CCSFA), C.cubensis is still present but in extremely low abundance $(\leq 1 \%)$, suggesting that the Tc occurrence of the species can be used to define the O4/O5 biozone boundary at $187.74 \mathrm{~m}$ CCSF-A. However, the two samples at 174.06 and $175.47 \mathrm{~m} \mathrm{CCSF-A} \mathrm{(17H-1} \mathrm{and}$ 17H-2 respectively), within Chron $\mathrm{C} 9 \mathrm{n}$, have the high- est occurrences of biserial planktonic forms in Hole U1334A. SEM analysis on 10 specimens from these two samples (Plate 4c-4l) confirms that these biserial forms are C.cubensis, so questions the use of Tc occurrence as a boundary marker at this site. A single, broken specimen was found within core section $16 \mathrm{H}-5$ (168.36 m CCSF-A) but was inferred as being reworked due to the poor preservation state and isolated occurrence of the specimen (Plate $4 \mathrm{~m}$ ).

\subsection{Morphometric analysis}

The measured specimens from Site U1334 are larger in width and length compared to those from Site 1237 (Fig. 7; Supplementary Tables S1 \& S2; Supplementary Fig. S3). The specimens from Site 1237 tend to show less variability in test size with length and width ranging between $110-160 \mu \mathrm{m}$ and $75-100 \mu \mathrm{m}$ respectively. Comparatively specimens from Site U1334 have a larger spread in test size with the majority of specimens having a test length of 170-240 $\mu \mathrm{m}$ and test width between 100-160 $\mu \mathrm{m}$. 


\subsection{SEM imaging}

The majority of specimens imaged from Site 1237 (Plates 1-2) and Site U1334 (Plates 3-4) possessed striae and so represented C.cubensis. A number of specimens imaged from both sites lacked striae and were tentatively identified as C.ototara (Plate 1c; 3a; 3k; 4a), however these specimens are recrystallized and comparatively poorly preserved so it is difficult to accurately assign these specimens to either $C$.cubensis or C.ototara.
Anomalous specimens were identified in both Site 1237 (Plate 1i) and U1334 (Plate 4e). While both specimens show the distinctive striae associated with $\mathrm{C}$. $\mathrm{Cu}$ bensis, the test morphology is more variable. The imaged specimen from Site 1237 (Plate 1i) has no clear final and penultimate chamber, with the arrangement of these chambers more closely resembling those of triserial forms. This specimen was recovered from a section in which the lithology changed from nannofossil ooze to partially lithified mudstone and may there-

Table 3 Relative (Rel. Abun.) and absolute abundance (Abso. Abun.) data for Hole U1334A showing samples, depths, ages and the inferred Chron and biozone for each sample.

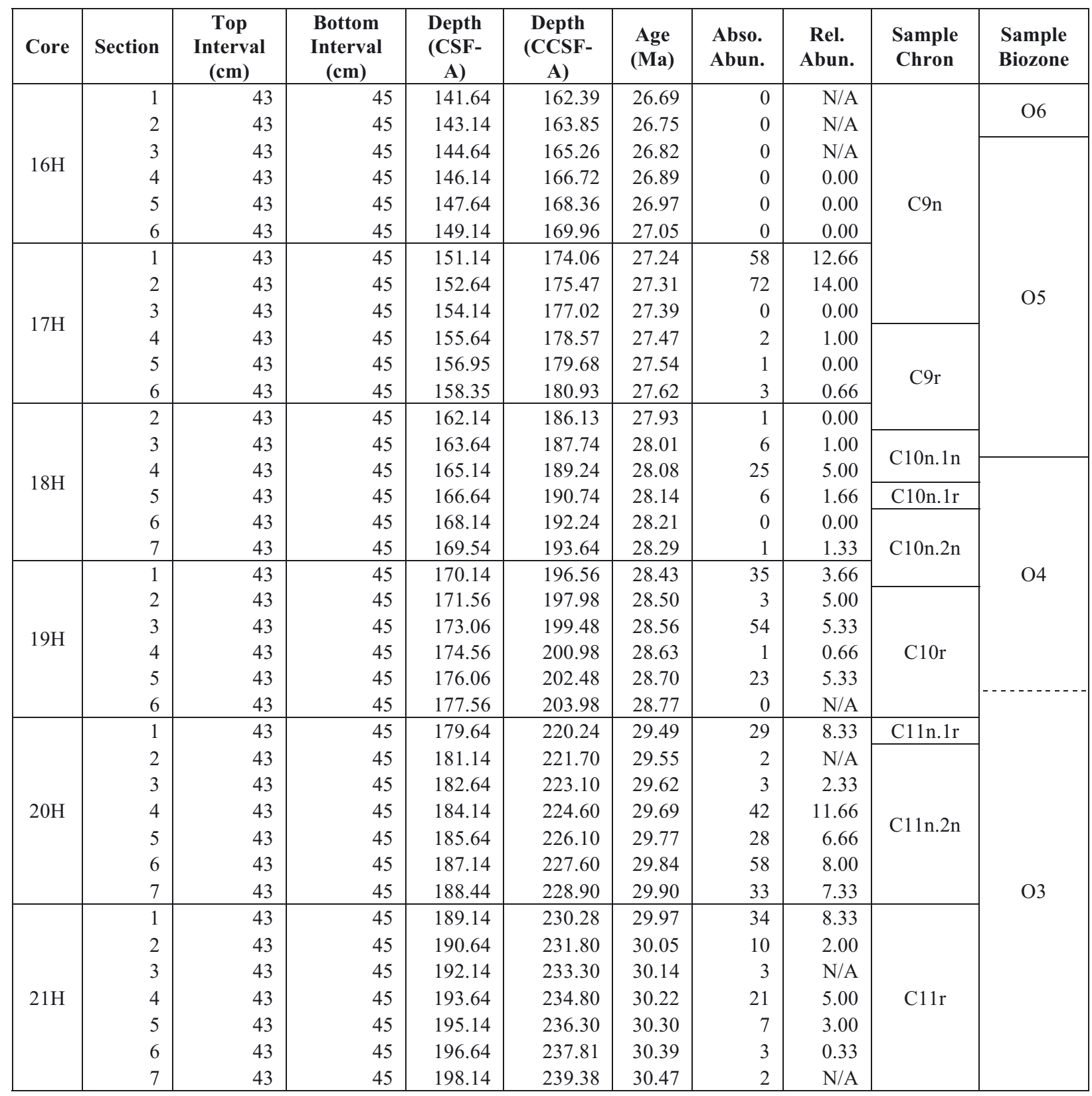




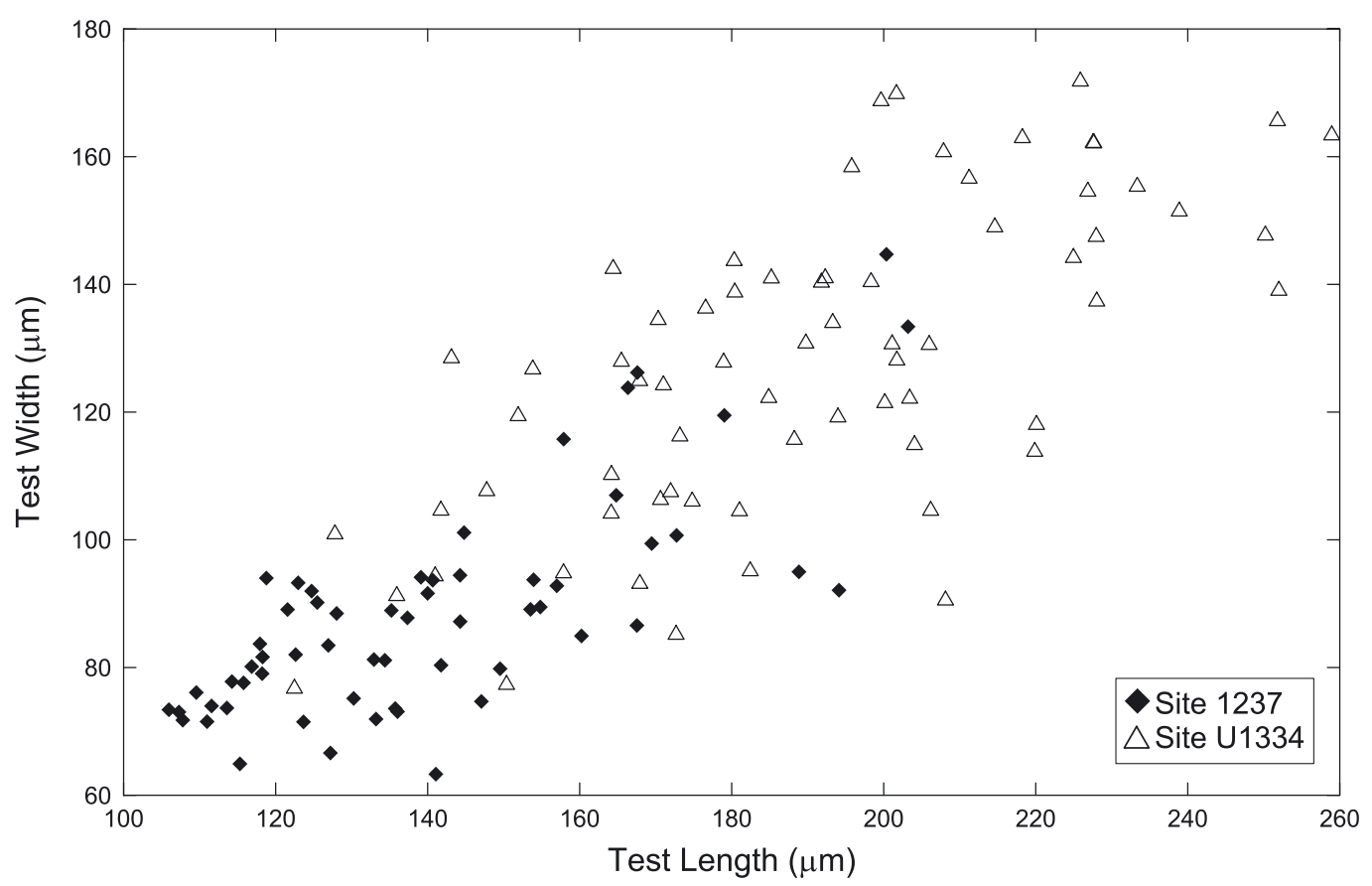

Fig. 7. Comparison of the length and width of measured tests of Chiloguembelina cubensis at Hole 1237B and Hole U1334A.

fore be more diagenetically altered than the other specimens hosted in nannofossil ooze. The specimen from Site U1334 (Plate 4e) has more ovate chambers in aperture view with an extremely wide low arched central aperture and more pronounced striae. This specimen does resemble the Mesozoic planktonic form Heterohelix globulosa, however the crust beneath Site U1334 extends only to the Eocene ( $38 \mathrm{Ma}$ ) (Expedition 320/321 Scientists 2010a) and no evidence of reworking or contamination is present within these samples. This therefore likely represents an end member of the $C$.cubensis morphospecies as no other specimens bear such an extreme morphology with all the other imaged specimens from this depth being consistent with the C.cubensis species concept.

On the whole the specimens from Site U1334 were better preserved then those from Site 1237, although nearly all of the specimens had some form of diagenetic alteration. The best preserved specimens from Site 1237 were found in core section $32 \mathrm{H}-1$ (291.85 mbsf) within Subchron C10n.1n, while the best preservation in Site U1334 was found in the upper Oligocene specimens in Chron C9n in core sections 17H-1 (174.06 m CCSF-A) and 17H-2 (175.47 m CCSF-A).

\section{Discussion}

\subsection{Revised age-depth model for Site 1237}

The revised age-depth model from the magnetostratigraphic and foraminifera datums shows four main changes in sedimentation rate (Fig.8), with two periods of slower sedimentation between 306.8-309 mbsf and $277.85-292.8 \mathrm{mbsf}$ with average rates of $2.5 \mathrm{~m} /$ my and $3.6 \mathrm{~m} / \mathrm{my}$ respectively, which are separated by a period of faster sedimentation $(8.4 \mathrm{~m} / \mathrm{my})$. In the uppermost Oligocene and extending into the lower Miocene (257.31-277.85 mbsf) the rate becomes faster with an average of $9.1 \mathrm{~m} / \mathrm{my}$. The Shipboard Scientific Party (2003) recorded an average rate between $8-9 \mathrm{~m} / \mathrm{my}$ for the Oligocene, and while this is consistent with the data between $292.8-306.8 \mathrm{mbsf}$, the rest of the Oligocene is generally markedly slower, although it is worth noting that the initial report only accounted for the biostratigraphic datums.

While the majority of data points closely agree with the revised age model, the Top Chron C10r (299.05 mbsf), the Top Tenuitella gemma (276.88 mbsf), Tc Trilobatus primordius (287.60 mbsf) and Base of Globoquadrina dehiscens (257.64 mbsf) plot slightly further from the idealised sedimentation line. However, the two former planktonic foraminifera species represent sec- 


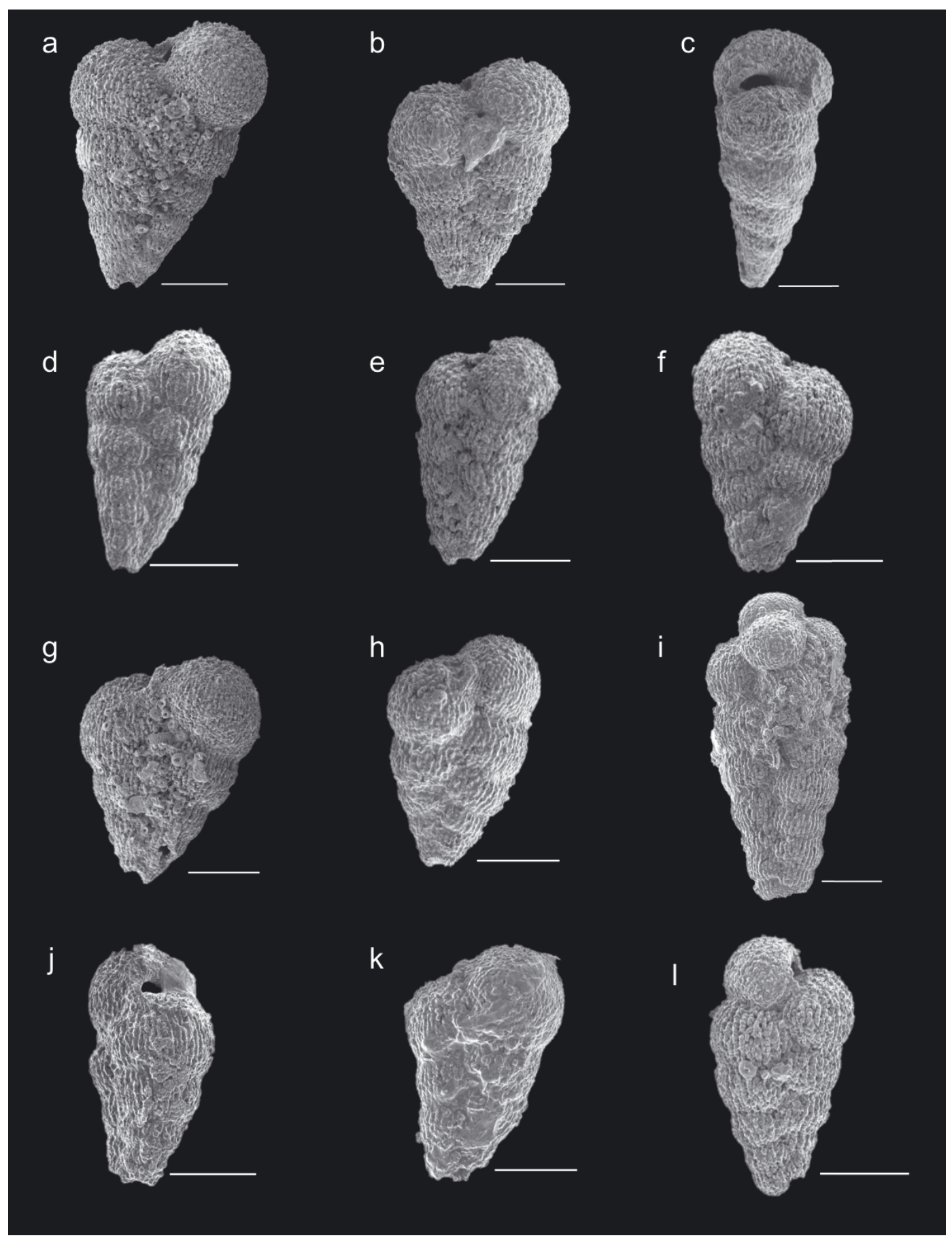

Plate 1. Chiloguembelina specimens from Hole 1237B. All images are separate specimens and scale bars are $50 \mu \mathrm{m}$. (a) C.cubensis lateral view, sample 202-1237B-34H-5, $85-87 \mathrm{~cm}, 316.37$ mbsf. (b) C.cubensis lateral view, sample 2021237B-34H-5, 85-87 cm, 316.37 mbsf. (c) ? C.ototara aperture view, sample 202-1237B-34H-3, 85-87 cm, 313.35 mbsf. (f) C.cubensis lateral view, sample 202-1237B-34H-1, 85-87 cm, 310.35 mbsf. (g) C.cubensis lateral view, sample $202-$ 1237B-34H-1, 85-87 cm, 310.35 mbsf. (h) C.cubensis lateral view, sample 202-1237B-34H-1, 85-87 cm, 310.35 mbsf. (i) C.cubensis lateral view, sample 202-1237B-33H-5, $85-87 \mathrm{~cm}, 306.88 \mathrm{mbsf}$. (j) C.cubensis lateral aperture view, sample 202-1237B-33H-1, 85-87 cm, 306.88 mbsf (k) C.cubensis lateral view, sample 202-1237B-32H-5, 85-87 cm, 297.39 mbsf. (l) C.cubensis lateral view, sample 202-1237B-32H-4, 35-37 cm, 295.4 mbsf. 


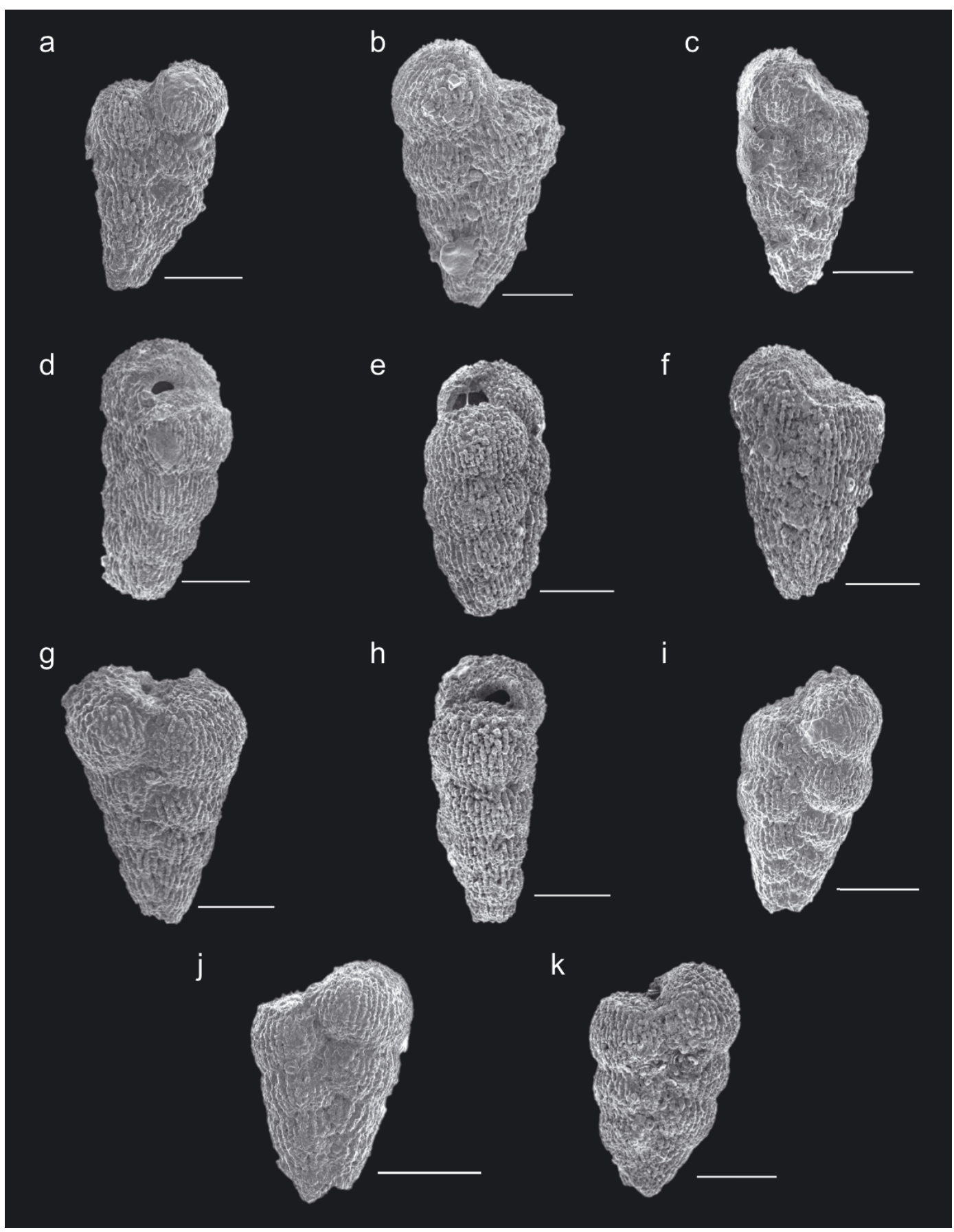

Plate 2. Chiloguembelina specimens from Hole 1237B. All images are separate specimens and scale bars are $50 \mu \mathrm{m}$. (a) C.cubensis lateral view, sample 202-1237B-32H-3, 85-87 cm, 294.38 mbsf. (b) C.cubensis lateral view, sample 2021237B-32H-3, 85-87 cm, 294.38 mbsf. (c) C.cubensis lateral view, sample 202-1237B-32H-3, 35-37 cm, 293.88 mbsf. (d) C.cubensis aperture view, sample 202-1237B-32H-3,35-37 cm, 293.88 mbsf. (e) C.cubensis aperture view, sample 2021237B-32H-2, 85-87 cm, 292.87 mbsf. (f) C.cubensis lateral view, sample 202-1237B-32H-2, 85-87 cm, 292.87 mbsf. (g) C.cubensis lateral view, sample 202-1237B-32H-2, 35-37 cm, 292.37 mbsf. (h) C.cubensis aperture view, sample 2021237B-32H-1, 135-137 cm, 291.85 mbsf. (i) C.cubensis lateral view, sample 202-1237B-32H-1, 85-87 cm, 291.35 mbsf. (j) C.cubensis lateral aperture view, sample 202-1237B-32H-1, 85-87 cm, $291.35 \mathrm{mbsf}(\mathrm{k})$ C.cubensis lateral view, sample 202-1237B-32H-1, 35-37 cm, 290.85 mbsf. 


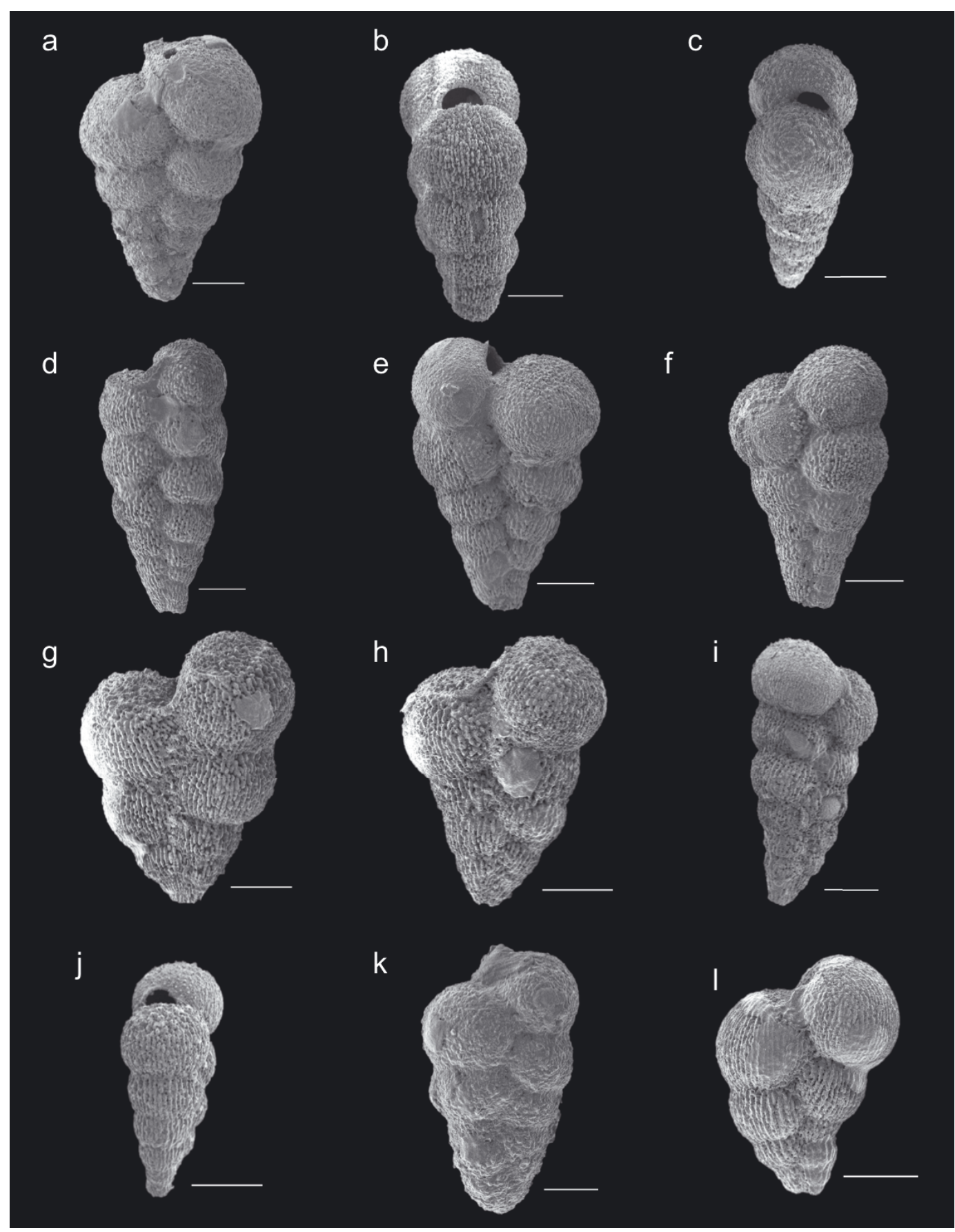

Plate 3. Chiloguembelina specimens from Hole U1334A. All images are separate specimens and scale bars are $50 \mu \mathrm{m}$. (a) ? C.ototara lateral view, sample 320-U1334A-21H-7, 43-45 cm, $239.38 \mathrm{~m}$ CCSF-A. (b) C.cubensis aperture view, sample 320-U1334A-21H-7, 43-45 cm, 239.38 m CCSF-A. (c) C.cubensis aperture view, sample 320-U1334A-21H-6, 43-45 cm, $237.81 \mathrm{~m}$ CCSF-A. (d) C.cubensis lateral view, sample 320-U1334A-21H-6, 43-45 cm, $237.81 \mathrm{~m}$ CCSF-A. (e) C.cubensis lateral view, sample 320-U1334A-20H-4, $43-45 \mathrm{~cm}, 224.60 \mathrm{~m}$ CCSF-A. (f) C.cubensis lateral view, sample 320-U1334A-20H-4, 224.60 m CCSF-A. (g) C.cubensis lateral view, sample 320-U1334A-20H-1, 43-45 cm, $220.24 \mathrm{~m}$ CCSF-A. (h) C.cubensis lateral view, sample 320-U1334A-20H-1, 43-45 cm, $220.24 \mathrm{~m}$ CCSF-A (i) C.cubensis lateral view, sample 320-U1334A-19H-3, 43-45 cm, $199.48 \mathrm{~m}$ CCSF-A. (j) C.cubensis aperture view, sample 320-U1334A19H-3, 43-45 cm, 199.48 m CCSF-A. (k) ? C. ototara lateral view, sample 320-U1334A-19H-1, $196.56 \mathrm{~m}, 43-45 \mathrm{~cm}$, CCSF-A. (1) C.cubensis lateral view, sample 320-U1334A-19H-1, 43-45 cm, 196.56 m CCSF-A. 


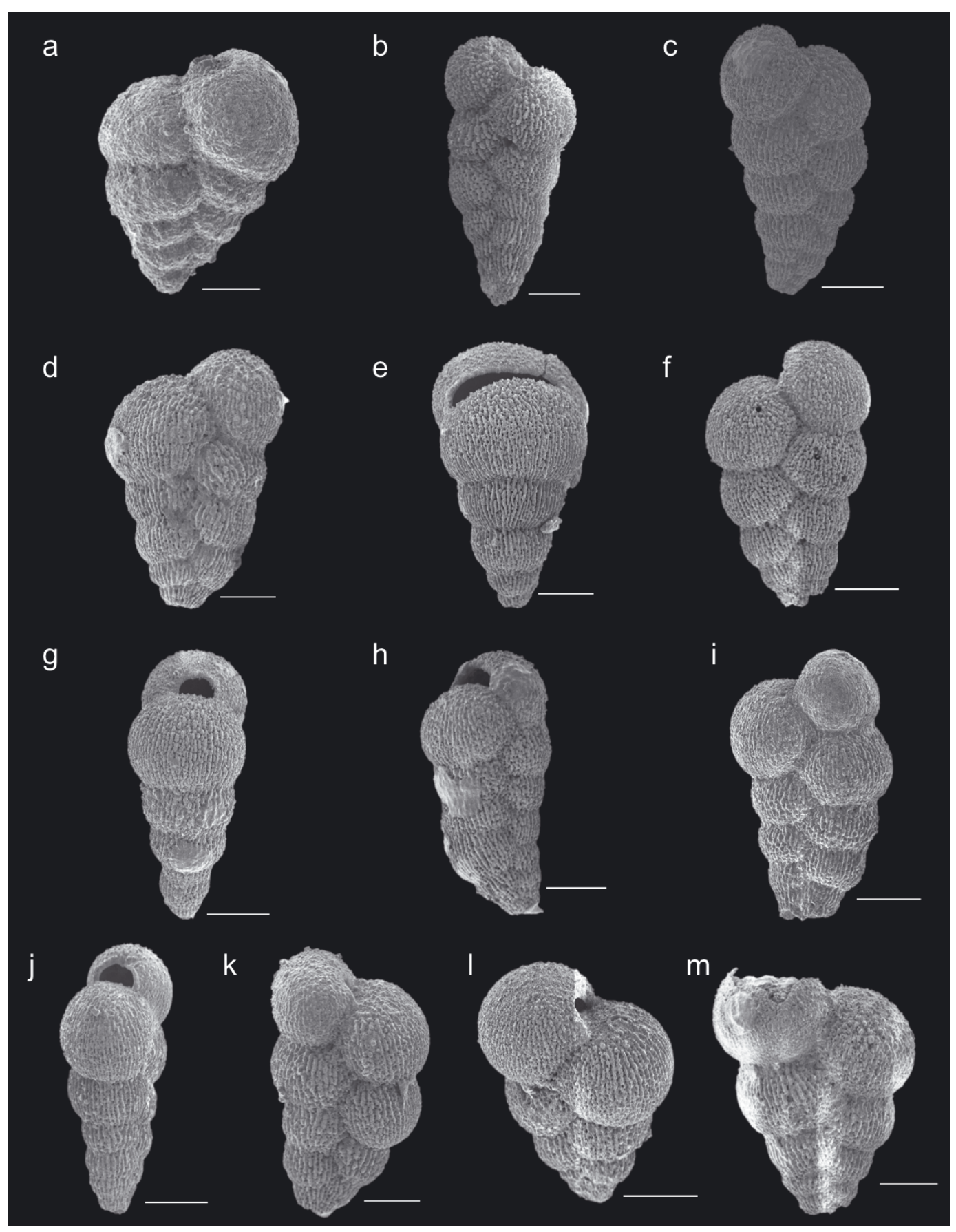

Plate 4. Chiloguembelina specimens from Hole U1334A. All images are separate specimens and scale bars are $50 \mu \mathrm{m}$. (a) ? C.ototara lateral view, sample 320-U1334A-18H-4, 43-45 cm, $189.24 \mathrm{~m}$ CCSF-A. (b) C.cubensis lateral view, sample 320-U1334A-18H-4, 43-45 cm, 189.24 m CCSF-A. (c) C.cubensis lateral view, sample 320-U1334A-17H-2, 43-45 cm, 175.47 m CCSF-A. (d) C.cubensis lateral view, sample 320-U1334A-17H-2, 43-45 cm, 175.47 m CCSF-A. (e) C.cubensis aperture view, sample 320-U1334A-17H-2,43-45 cm, 175.47 m CCSF-A. (f) C. cubensis lateral view, sample 320-U1334A17H-2, 43-45 cm, 175.47 m CCSF-A. (g) C.cubensis aperture view, sample 320-U1334A-17H-2, $43-45 \mathrm{~cm}, 175.47 \mathrm{~m}$ CCSF-A. (h) C.cubensis lateral view, sample 320-U1334A-17H-2, 43-45 cm, $175.47 \mathrm{~m}$ CCSF-A. (i) C.cubensis lateral view, sample 320-U1334A-17H-1, 43-45 cm, $174.06 \mathrm{~m}$ CCSF-A. (j) C.cubensis aperture view, sample 320-U1334A17H-1, 43-45 cm, $174.06 \mathrm{~m}$ CCSF-A. (k) C.cubensis lateral view, sample 320-U1334A-17H-1, 43-45 cm, $174.06 \mathrm{~m}$ CCSF-A. (1) C.cubensis lateral view, sample 320-U1334A-17H-1, 43-45 cm, $174.06 \mathrm{~m}$ CCSF-A. (m) C.cubensis lateral view, sample 320-U1334A-16H-5, 43-45 cm, 168.36 m CCSF-A (reworked?). 


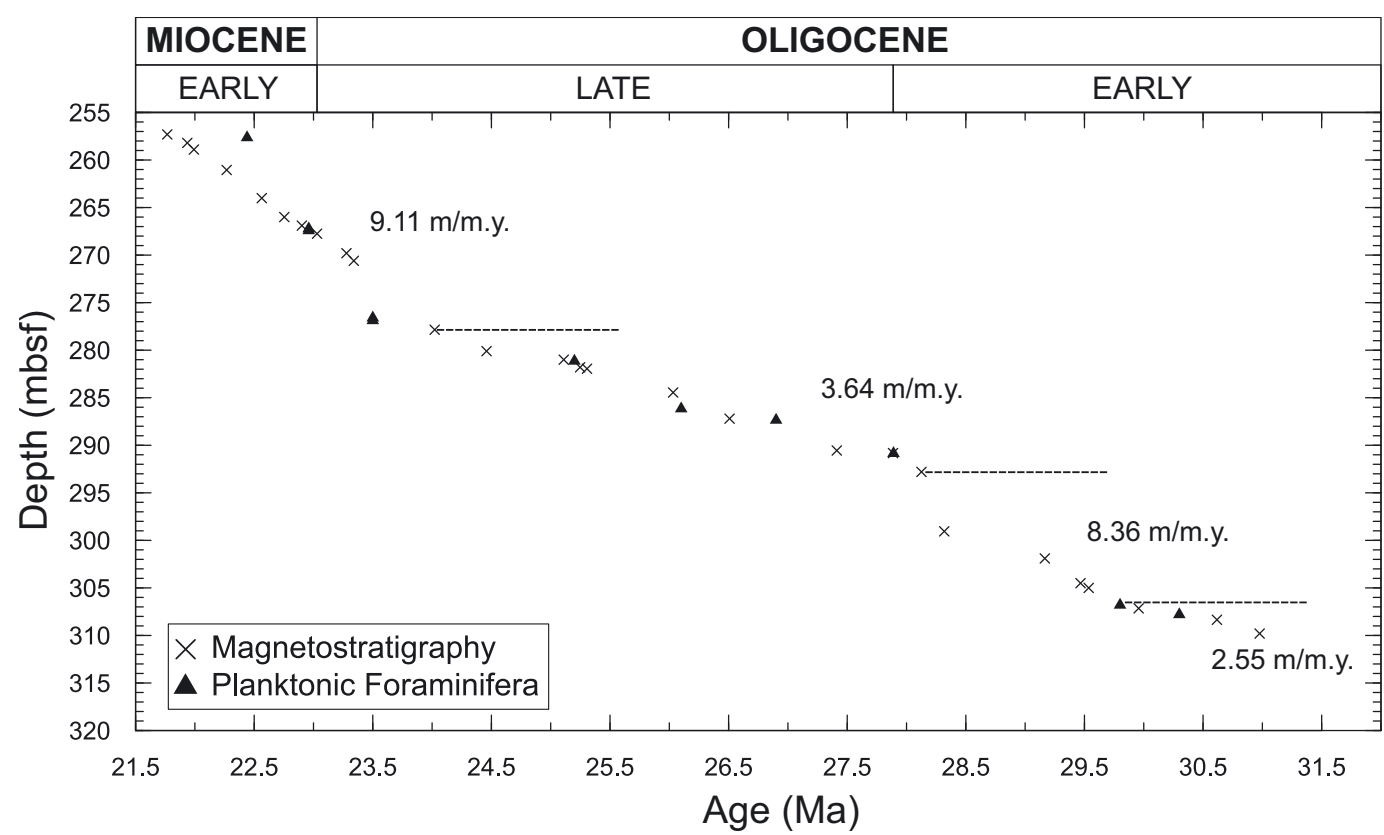

Fig. 8. Revised age depth model for Site 1237, taking into account datums presented in Table 1.

ondary marker species, so may not be as well constrained as those primary markers. In the case of G.dehiscens the degree of depth error associated with the planktonic foraminifera bioevents is likely to be responsible. The interval around Top Chron C10r is a period where the inclination and declination became unclear which led to Chron 10n.2n not being interpreted (Fig. 3).

\subsection{The extinction of Chiloguembelina cubensis}

The primary aim from the analysis of Site 1237 and Site U1334 was to determine the biostratigraphic utility of C.cubensis. The results from Hole 1237B strongly support C.cubensis as a distinct bioevent. The species is observed at $290.85 \mathrm{mbsf}(32 \mathrm{H}-1)$ and is absent in the next upcore sample at $290.82 \mathrm{mbsf}(31 \mathrm{H}-7)$, allowing for an extremely precise extinction level due to the increased sampling resolution $(290.835 \pm 0.015$ mbsf; Tables 2, 4, Fig.5). This level is equivalent to upper Subchron C10n.1n, which when directly correlated to various time scales (Table 4) gives an age of $28.285 \mathrm{Ma}$ (Cande and Kent 1995), 28.188 Ma (Luterbacher et al. 2004) and 27.888 Ma (Pälike et al. 2006). These findings are consistent with other Oligocene mid latitude sites $\left(20-40^{\circ} \mathrm{S}\right)$ from ODP expeditions, namely The Great Australian Bight, Leg 182 Sites 1130 and 1134 (Li et al. 2003), which find an abrupt extinction of

Table 4 Depth and age of Top C.cubensis in Hole 1237B. Calibrated ages to the palaeomagnetic chronologies of Cande and Kent (1995) and Luterbacher et al. (2004), and the astronomical time scale of Pälike et al. (2006).

\begin{tabular}{lccc}
\hline Sample & Sample ID & Depth (mbsf) & Depth (mcd) \\
\hline Lowermost sample without C. cubensis & $31 \mathrm{H}-7,57-77 \mathrm{~cm}$ & 290.820 & 326.230 \\
Midpoint & N/A & 290.835 & 327.445 \\
Uppermost sample with C. cubensis & $32 \mathrm{H}-1,35-37 \mathrm{~cm}$ & 290.850 & 328.660 \\
\hline Time Scale & Cande and Kent (1995) & Luterbacher et al. (2004) & Pälike et al. \\
Youngest Age (Ma) & & 28.186 & 27.886 \\
Inferred Age (Ma) & 28.283 & 28.188 & 27.888 \\
Oldest Age (Ma) & 28.285 & 28.190 & 27.890 \\
\hline
\end{tabular}


C.cubensis in the mid Oligocene (Subchron C10n.1n). The age inferred from Site 1237 is $\sim 100$ kyr younger than other sites using the species as a boundary marker, which have an age of $\sim 28$ Ma when astronomically calibrated (e.g. Berggren 1992, Wade et al. 2007). This younger age is likely a reflection on the high sampling resolution $(3 \mathrm{~cm})$ through the extinction interval.

The results from Hole U1334A are contrasting to those from Hole 1237B. A peak abundance of C.Cubensis occurs in the upper Oligocene within Chron C9n, with an astronomical age for the Top occurrence being $\sim 27.15 \mathrm{Ma}$ (as per Pälike et al. 2006). This raises questions regarding the biostratigraphic utility of $\mathrm{C} . \mathrm{Cu}$ bensis as a reliable marker, at least at Site U1334. Although Tc occurrence of the species has become the widely accepted boundary maker (Berggren et al. 1995, Berggren and Pearson 2005, Coccioni et al. 2008, Wade et al. 2011), this is on the basis of rarer $(<5 \%)$ and sporadic occurrences of $C$.cubensis in the upper Oligocene (e.g. Huber 1991, Leckie et al. 1993). While this is consistent with the low abundance observed through Chron C9r, the rapidity of the peak abundance and inferred extinction at $172.01 \pm 2.05 \mathrm{~m}$ CCSF-A within the basal region of Chron C9n $(\sim 27.15 \mathrm{Ma})$ presents a previously unobserved phenomenon within C.cubensis. The species is susceptible to reworking (e.g. Poore et al. 1984, Pearson 1995, Wade et al. 2007) and while such a process can never be fully discounted, it is unlikely that this is the reason for this peak in abundance. The planktonic foraminiferal assemblages observed are consistent with upper Oligocene taxa, with no evidence of other reworked taxa, and SEM analysis shows that planktonic foraminifera at this level are well preserved. In addition, reworking is not identified through the core $17 \mathrm{H}$ interval in other microfossil groups, such as the calcareous nannofossils (Bown and Dunkley Jones 2012) and radiolarians (Expedition 320/321 Scientists 2010a). The lack of reworking in any of the microfossils groups therefore suggests this peak is a true occurrence of C.cubensis. Our new data from Site U1334 contrasts to nearby Site 1218 where Wade et al. (2007) found an extinction in Subchron C10n.1n with no higher recorded occurrences in younger sediments. However, Site 1218 is extremely siliceous rich through this interval and the foraminiferal preservation is inferior to Site U1334 (Wade et al. 2016). In addition, abundance counts were not employed in the planktonic foraminifera biostratigraphy, so these reasons likely account for this discrepancy between the two sites.

Van Simaeys et al. (2004) questioned the utility of C.cubensis as a reliable boundary marker on the basis that the extinction event is diachronous and latitudinally controlled. By considering the sites which possess a magnetostraigraphic record through the mid Oligocene and where C.cubensis is present (Fig.9), it can be seen there is no clear latitudinal control on the extinction level of the species.

The results from Site 1237 and the global comparison dataset (Fig.9), confirm that there is a large scale global decline in the population of C.cubensis in the mid Oligocene. Previous authors have suggested an abundance threshold of 5\% to define the Tc C.cubensis, the peak abundance within Chron C9n at Site U1334 indicates that the Tc occurrence of 5\% may not be the best criterion. In addition, the relative abundance datasets presented in this study (Figs. 4 and 5), records from the southern Spain (Alegret et al. 2008) and the northern Adriatic Sea (Hernitz Kucejak et al. 2014) show abundances below $5 \%$ through some periods of the early Oligocene. Therefore, applying the Tc criterion for C.cubensis may prove difficult due to fact the record seems to fluctuate somewhat erratically. By taking into consideration these factors, we suggest that the new phrase "Chiloguembelina cubensis crisis" best describes the event in the mid Oligocene.

\subsection{Controls on the abundance of Chiloguembelina cubensis at Sites 1237 and U1334}

At Site U1334 there is a clear link between the abundance of radiolarians and planktonic foraminifera, as high radiolarian abundance is coincidental with low planktonic foraminiferal abundance and vice versa. A similar link between abundances of these two microfossil groups has been recorded in the Oligocene and Eocene in the equatorial Atlantic Ocean at Ceara Rise (Diester-Haass and Zachos 2003). The abundance of C.cubensis was found to decrease following oxygen isotope (Oi) events in the Adriatic Sea (HernitzKučenjak et al. 2014). However, we find little correlation between the high resolution stable isotope record at nearby Site 1218 (Wade and Pälike 2004) and our abundance data (Supplementary Fig. S1 and S2), suggesting that abundance is not controlled by palaeoceanographic factors. However, the onset of peak abundance in C.cubensis in Chron C9n is near synchronous with a positive shift in the planktonic $\delta^{18} \mathrm{O}$ record (Supplementary Fig. S1) which was attributed to a migration of D.venezuelana to a deeper depth habitat (Wade and Pälike 2004). 


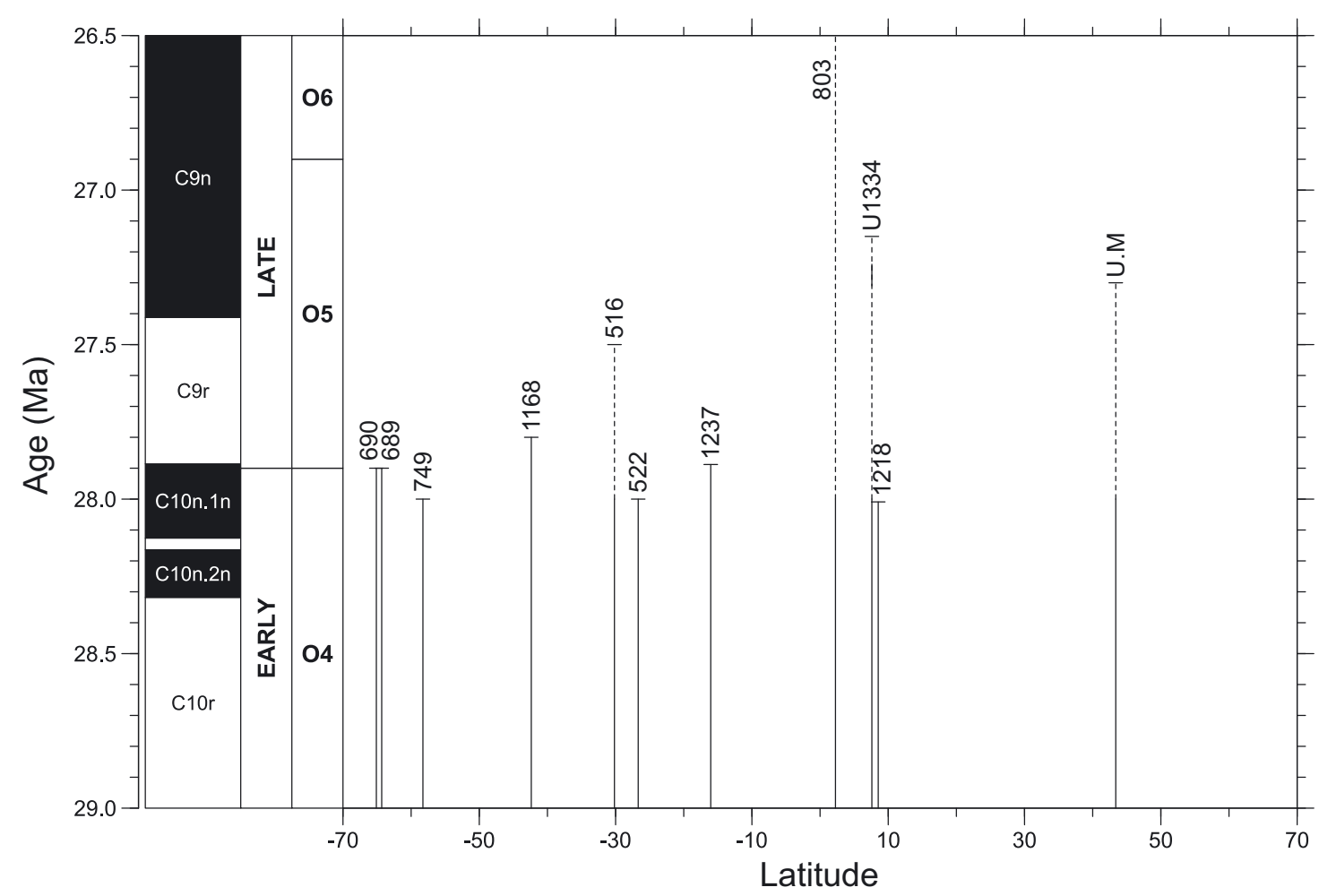

Fig. 9. Extinction levels for Chiloguembelina cubensis which have been calibrated to the palaeomagnetic timescale, relative to the latitude of each site. Data comes from ODP Leg 113 Sites 689 and 690 (Stott and Kennett 1990), ODP Leg 120 Site 749 (Berggren 1992), ODP Leg 189 Site 1168 (Stickley et al. 2004), DSDP Leg 72 Site 516 (Berggren et al. 1983), DSDP Leg 73 Site 522 (Poore et al. 1984), ODP Leg 202 Site 1237 (this study), ODP Leg 130 Site 803 (Leckie et al. 1993), IODP Exp. 320 Site U1334 (this study), ODP Leg 199 Site 1218 (Wade et al. 2007) and the Umbra Marche Basin (U.M) (Coccioni et al. 2008, 2013).

The causal mechanism for the peak abundance of C.cubensis at Site U1334 is unclear, reworking has been discounted based on previously discussed evidence (Section 5.2). Boersma and Premoli Silva (1989) found that Cenozoic biserial planktonic foraminifera had the most depleted $\delta^{13} \mathrm{C}$ values and suggested these forms occupied the oxygen minimum zone. We therefore speculate that a localised, temporary expansion of the oxygen minimum zone may have led to this peak in abundance in C9n. The enhanced abundance is coincidental with a period of gigantism in Paragloborotalia opima (Wade et al. 2016) and the migration to deeper depths observed in Dentoglobigerina venezuelana at Site U1334 (Matsui et al. 2016) and Site 1218 (Wade and Pälike 2004; Supplementary Fig. S1), which Matsui et al. (2016) suggested was coincidental with a deepening of the thermocline. The synchronicity of the peak in C.cubensis, gigantism in P.opima and depth migration of D. venezuelana suggests that these events may have been driven by complex changes in oceano- graphy, at least on a localised scale through Chron C9n at Site U1334.

At Site 1237 the abundance of biserial planktonic foraminifera is greatest in Zone O2. This is consistent with records for the mid-latitude sections of Spain and the Adriatic Sea (Alegret et al. 2008, Hernitz-Kučenjak et al. 2014) at least for the basal part of Zone O2. This peak in abundance is likely due to the co-current range of both C.cubensis and C.ototara through the more basal region of Zone O2, while in the latter part of Zone $\mathrm{O} 2$ only C.cubensis is occurring so explains why the relative abundance of biserial forms begins to decline and remains relatively low through the rest of the record at Site 1237.

\subsection{Size Dynamics of Chiloguembelina cubensis}

Using the modern planktonic foraminifera as an analogue, the largest test size for a given species is ob- 
served in the most optimal conditions (Schmidt et al 2006), while the largest test sizes for an overall assemblage are found within subtropical oligotrophic gyres (Kucera 2007) with size being found to decline in high productivity, upwelling areas (Schmidt et al. 2004a). While limitations exist, if the life cycle is viewed in terms of the $\mathrm{r} / \mathrm{K}$ selection theory it should follow that r-selectors reproduce quickly and grow to a smaller size due to a variable or unpredictable climate (e.g. upwelling environments), while K-selectors are associated with the opposite, this being a larger size and slower reproduction associated with predictable and near constant climatic conditions (e.g. oligotrophic gyres) (Pianka 1971). In the fossil record there is little difference in the overall test size of the planktonic foraminiferal assemblages in the mid-high and low latitudes prior to $\sim 42 \mathrm{Ma}$, but the latitudinal offset becomes more pronounced from the Eocene-Oligocene boundary ( $34 \mathrm{Ma}$ ) onwards and remains the case until the modern day (Schmidt et al. 2004b). Therefore, by taking these factors into consideration it is possible to deduce what the key control is on the test size of C.cubensis test size at least between these two sites. When compared it can clearly be seen that the specimens from Site U1334 are longer and wider than specimens in Site 1237 (Fig.7), this therefore suggests the latitudinal offset, and hence temperature, is the most important control on test size at least in terms of the studied sites.

\section{Conclusions}

Based on our quantitative biostratigraphic analyses from the Pacific Ocean, the biostratigraphic value of C.cubensis as a correlation event for the base of the Chattian remains unclear. Site 1237 strongly supports the utility of the species as a reliable bioevent, whereas the results from Site U1334 show peak abundances in the late Oligocene (C9n). While the Tc occurrence of C.cubensis has become the favourable bioevent for the boundary marker, this is on the basis that the upper Oligocene occurrences of the species are rarer and more sporadic, which is not supported by our data from Site U1334. Our compilation from ocean drilling and land sections shows that there is no latitudinal control on the extinction level of C.cubensis, however we do find differences in test size between the two studied sites, which we suggest is controlled by temperature. We pen the phrase "Chiloguembelina cubensis crisis" to describe the extinction or reduction in the abundance in C.cubensis in the mid Oligocene.
Acknowledgements. This research was undertaken as part of an MSc in Geoscience at UCL. Scanning Electron Microscope (SEM) analyses was funded by UCL. BW was supported by the UK Natural Environment Research Council (NERC) reference number NE/G014817, Marie Curie Career Integration Grant 293741 "ERAS", and a UK-IODP Rapid Response Award. We extend our gratitude to Mark Turmaine for assisting with SEM analyses, Thomas Westerhold for assistance with sample age and depth at Site U1334, and three anonymous reviewers for their insightful comments and recommendations to help improve the manuscript. Samples were provided by the Integrated Ocean Drilling Program (IODP). IODP is sponsored by the U.S. National Science Foundation and participating countries.

\section{References}

Agnini, C., Fornaciari, E., Giusberti, L., Grandesso, P., Lanci, L., Luciani, V., Muttoni, G., Pälike, H., Rio, D., Spofforth, D. J.A., Stefani, C., 2011. Integrated bio-magnetostratigraphy of the Alano section (NE Italy): a proposal for defining the Middle-Late Eocene boundary. Geological Society of America Bulletin 123, 841-872.

Alegret, L., Cruz, L.E., Fenero, R., Molina, E., Ortiz, S., Thomas, E., 2008. Effects of the Oligocene climatic events on the foraminiferal record from Fuente Caldera section (Spain, western Tethys). Palaeogeography, Palaeoclimatology, Palaeoecology 269, 94-102.

Backman, J., Raffi, I., Rio, D., Fornaciari, E., Pälike, H., 2012. Biozonation and biochronology of Miocene through Pleistocene calcareous nannofossils from low and middle latitudes. Newsletters on Stratigraphy 45, 221-244.

Barron, J. A., Baldauf, J. G., Barrera, E., Caulet, J.-P., Huber, B.T., Keating, B.H., Lazarus, D., Sakai, H., Thierstein, H. R., Wei, W., 1991. Biochronologic and magnetochronologic synthesis of Leg 119 sediments from the Kerguelen Plateau and Prydz Bay, Antarctica. In: Barron, J., Larsen, B. et al. (Eds.), Proceedings of the Ocean Drilling Program, Scientific Results, v.119. College Station, Texas (Ocean Drilling Program), 813-847.

Beckmann, J.P., 1957. Chiloguembelina Loeblich and Tappan and related Foraminifera from the lower Tertiary of Trinidad. United States National Museum Bulletin 215, 83-95.

Berggren, W. A., Pearson, P.N., 2005. A revised tropical to subtropical Paleogeneplanktonic foraminiferal zonation. Journal of Foraminiferal Research 35, 279-298.

Berggren, W.A., Kent, D. V., Flynn, J.J., Van Couvering, J. A., 1985. Cenozoic geochronology. Geological Society of America Bulletin 96, 1407-1418.

Berggren, W. A., Kent, D. V., Swisher III, C. C., Aubry, M.-P., 1995. A revised Cenozoic geochronology and chronostratigraphy. In: Berggren, W.A., Kent, D. V., Aubry, M.-P., Hardenbol, J. (Eds.), Geochronology, Time Scales and Global Stratigraphic Correlation: A Unified Temporal Framework for an Historical Geology: SEPM Special Publication 54, 129-212. 
Berggren, W. A., 1971. Multiple phylogenetic zonations of the Cenozoic based on planktonic foraminifera. In: Farinacci, A. (ed.), Proceedings of the II Planktonic Conference, Roma 1970, Edizioni Tecnoscienza, Roma, 41-56.

Berggren, W.A., 1992. Paleogene planktonic foraminifer magnetobiostratigraphy of the southern Kerguelen Plateau (Sites 747-749). In: Wise, S. W., Jr., Schlich, R. et al. (Eds.), Proceedings of the Ocean Drilling Program, Scientific Results, v. 120. College Station, Texas (Ocean Drilling Program), 551-568.

Berggren, W.A., Amdurer, M., 1973. Late Paleogene (Oligocene) and Neogene planktonic foraminiferal biostratigraphy of the Atlantic Ocean (lat. $30^{\circ} \mathrm{N}$ to lat. $30^{\circ} \mathrm{S}$ ). Revista Italiana di Paleontologia e Stratigrafia 79, 537592.

Berggren, W.A., Hamilton, N., Johnson, D.A., Pujol, C., Weiss, W., Cepek, P., Gombos, A.M., 1983. Magnetobiostratigraphy of Deep Sea Drilling Project Leg-72, Sites 515-518, Rio-Grande rise (South-Atlantic). In: Barker, P. F., Carlson, R.L., Johnson, D. A., et al., Initial Reports of the Deep Sea Drilling Project, v. 72. Washington, D.C., U.S. Government Printing Office, 939-947.

Blow, W.H., 1969. Late Middle Eocene to Recent planktonic foraminiferal biostratigraphy. In: Brönnimann, P., Renz, H.H. (Eds.), Proceedings of the First International Conference on Planktonic Microfossils, 1. E. J. Brill, Leiden, 199-422.

Boersma, A., Silva I.P., 1989. Atlantic paleogene biserial heterohelicid foraminifera and oxygen minima. Paleoceanography 4, 271-286.

Bown, P.R., Dunkley Jones, T., 2012. Calcareous nannofossils from the Paleogene equatorial Pacific (IODP Expedition 320 Sites U1331-1334). Journal of Nannoplankton Research 32, 3-51.

Cande, S.C., Kent, D. V., 1995. Revised calibration of the geomagnetic polarity timescale for the Late Cretaceous and Cenozoic. Journal of Geophysical Research 100, 6093-6095.

Coccioni, R., Marsili, A., Montanari, A., Bellanca, A., Neri, R., Bice, D. M., Brinkhuis, H., Church, N., Macalady, A., McDaniel, A., Deino, A., Lirer, F., Sprovieri, M., Maiorano, P., Monechi, S., Nini, C., Nocchi, M., Pross, J., Rochette, P., Sagnotti, L., Tateo, F., Touchard, Y., Van Simaeys, S., Williams, G.L., 2008. Integrated stratigraphy of the Oligocene pelagic sequence in the UmbriaMarche basin (northeastern Apennines, Italy): a potential Global Stratotype Section and Point (GSSP) for the Rupelian/Chattian boundary. Geological Society of America Bulletin 120, 487-511.

Coccioni, R., Sideri, M., Bancalà, G., Catanzariti, R., Frontalini, F., Jovane, L., Montanari, A., Savian, J., 2013. Integrated stratigraphy (magneto-, bio- and chronostratigraphy) and geochronology of the Palaeogene pelagic succession of the Umbria-Marche Basin (central Italy). In: Jovane, L., Herrero-Bervera, E., Hinnov, L. A., Housen, B. A. (Eds.), Magnetic Methods and the Timing of Geological Processes: Geological Society, London, Special Publications 373, 111-131.
Cohen, K. M., Finney, S. C., Gibbard, P. L., Fan, J. X., 2013. The ICS International Chronostratigraphic Chart. Episodes 36, 199-204.

Cushman, J.A., 1924. The use of Foraminifera in geologic correlation. American Association of Petroleum Geologists Bulletin 8, 485-491.

Cushman, J. A., Stainforth, R.M.S., 1945. The foraminifera of the Cipero Marl Formation of Trinidad, British West Indies. Cushman Laboratory for Foraminiferal Research. Special Publication 14, 1-75.

Diester-Haass, L., Zachos, J.C., 2003. The Eocene-Oligocene transition in the equatorial Atlantic (ODP Site 925): paleoproductivity increase and positive ${ }^{13} \mathrm{C}$ excursion. In: Prothero, D. R., Ivany, L.C., Nesbitt, E. A. (Eds.), From Greenhouse to Icehouse: The Marine Eocene-Oligocene Transition. Columbia University Press, New York, $397-$ 416. The Marine Eocene-Oligocene Transition. Columbia University Press, New York, p. 397-416.

Expedition 320/321 Scientists, 2010a. Site U1334. In: Pälike, H., Lyle, M., Nishi, H., Raffi, I., Gamage, K., Klaus, A., and the Expedition 320/321 Scientists, Proceedings of the Integrated Ocean Drilling Program, v. 320/321. Tokyo (Integrated Ocean Drilling Program Management International, Inc.).

Expedition 320/321 Scientists, 2010b. Site U1336. In: Pälike, H., Lyle, M., Nishi, H., Raffi, I., Gamage, K., Klaus, A., and the Expedition 320/321 Scientists, Proceedings of the Integrated Ocean Drilling Program, v. 320/321. Tokyo (Integrated Ocean Drilling Program Management International, Inc.).

Flower, B.P., Chisholm, K.E., 2006. Magnetostratigraphic calibration of the late Oligocene climate transition. In: Tiedemann, R., Mix, A.C., Richter, C., Ruddiman, W.F. (Eds.), Proceedings of the Ocean Drilling Program, Scientific Results, v.202. College Station, Texas (Ocean Drilling Program), 1-15.

Hailwood, E.A., Clement, B.M., 1991. Magnetostratigraphy of Sites 703 and 704, Meteor Rise, southeastern South Atlantic. In: Ciesielski, P.F., Kristoffersen, Y. et al. (Eds.), Proceedings of the Ocean Drilling Program, Scientific Results, v.114. College Station, Texas (Ocean Drilling Program), 367-386.

Herman, Y., 1992. Eocene through Quaternary planktonic foraminifers from the northwest Pacific, Leg 126. In: Taylor, B., Fujioka, K. et al. (Eds.), Proceedings of the Ocean Drilling Program, Scientific Results, v. 126. College Station, Texas (Ocean Drilling Program), 271284.

Hernitz Kucenjak, M., Premec Fucek, V., Huber, B.T., Wade, B.S., 2014. The test size and abundance variations in planktonic foraminifera Chiloguembelina cubensis and C.ototara as response to climatic events in Oligocene. Rendiconti Online Societa Geologica Italiana 31, $103-$ 104. doi:10.3301/ROL.2014.68.

Hess, J., Stott, L. D., Bender, M.L., Kennett, J.P., Schilling, J.-G., 1989. The Oligocene marine microfossil record: age assessments using Strontium isotopes. Paleoceanography 4, 655-679. 
Hornibrook, N.D. B., 1990. Chiloguembelina cubensis (Palmer) and C.ototara (Finlay). In: New Zealand. Journal of Foraminiferal Research 20,368-371.

Huber, B. T., Quillévéré, F., 2005. Revised Paleogene planktonic foraminiferal biozonation for the Austral Realm. Journal of Foraminiferal Research 35, 299-314.

Huber, B. T., 1991. Paleogene and early Neogene planktonic foraminifer biostratigraphy of Sites 738 and 744, Kerguelen Plateau (southern Indian Ocean). In: Barron, J., Larsen, B. et al. (Eds.), Proceedings of the Ocean Drilling Program, Scientific Results, v.119. College Station, Texas (Ocean Drilling Program), 427-449.

Huber, B.T., Olsson, R. K., Pearson, P. N., 2006. Taxonomy, biostratigraphy and phylogeny of Eocene microperforate planktonic foraminifera (Jenkinsina, Cassigerinelloita, Chiloguembelina, Streptochilus, Zeauvigerina, Tenuitella, and Cassigerinella) and problematica (Dipsidripella). In: Pearson, P. N., Olsson, R. K., Huber, B. T., Hemleben, C., Berggren, W. A. (Eds.), Atlas of Eocene Planktonic Foraminifera, Cushman Foundation Special Publication 41, 461-508.

Janus Web Database (http://www-odp.tamu.edu/database/).

Jenkins, D.G., 1966. Planktonic foraminiferal zones and new taxa from the Danian to Lower Miocene of New Zealand. New Zealand Journal of Geology and Geophysics $8,1088-1126$.

Jenkins, D.G., 1985. Southern mid-latitude Paleocene to Holocene planktic foraminifera. In: Bolli, H.M., Saunders, J.B., Perch-Nielsen, K. (Eds.), Plankton Stratigraphy, Volume 1: Cambridge University Press, Cambridge, 263-282.

Jenkins, D. G., Orr, W., 1972. Planktonic foraminiferal biostratigraphy of the Eastern Equatorial Pacific Ocean DSDP Leg 9. In: Hays, J. D. et al., Initial Reports of the Deep Sea Drilling Project, v.9. Washington, D.C., U.S. Government Printing Office, 1059-1193.

Jenkins, D. G., Srinivasan, M. S., 1986. Cenozoic planktonic foraminifers from the Equator to the Sub-Antarctic of the Southwest Pacific Ocean. In: Kennett, J.P., von der Borch, C.C. et al. Initial Reports of the Deep Sea Drilling Project, v. 90. Washington, D.C., U.S. Government Printing Office, 795-834.

Jovane, L., Sprovieri, M., Coccioni, R., Florindo, F., Marsili, A., Laskar, J., 2010. Astronomical calibration of the middle Eocene Contessa Highway section (Gubbio, Italy). Earth and Planetary Science Letters 298, 77-88.

Kelly, D.C., Norris, R. D., Zachos, J.C., 2003. Deciphering the paleoceanographic significance of Early Oligocene Braarudosphaera chalks in the South Atlantic. Marine Micropaleontology 49, 49-63.

Kucera, M., 2007. Planktonic foraminifera as tracers of past oceanic environments. In: Hillaire-Marcel, C., de Vernal, A. (Eds.), Methods in late Cenozoic paleoceanography. Elsevier, 225-266.

Leckie, R.M., Farnham, C., Schmidt, M.G., 1993. Oligocene planktonic foraminifer biostratigraphy of Hole 803D (Ontong Java Plateau) and Hole 628A (Little Bahama Bank), and comparison with the southern high lat- itudes. In: Berger, W.H., Kroenke, L. W., Mayer, L. A. et al. (Eds.), Proceedings of the Ocean Drilling Program, Scientific Results, v. 130. College Station, Texas (Ocean Drilling Program), 3-136.

Li, Q., Jian, Z., Li, B., 2004. Oligocene-Miocene planktonic foraminifer biostratigraphy, Site 1148, northern South China Sea. In: Prell, W. L., Wang, P., Blum, P., Rea, D. K., Clemens, S.C. (Eds.), Proceedings of the Ocean Drilling Program, Scientific Results, v.182. College Station, Texas (Ocean Drilling Program), 1-26.

Li, Q., McGowran, B., James, N.P., 2003. Eocene-Oligocene planktonic foraminiferal biostratigraphy of Sites 1126, 1130, 1132, and 1134, ODP Leg 182, Great Australian Bight. In: Hine, A.C., Feary, D. A., Malone, M. J. (Eds.), Proceedings of the Ocean Drilling Program, Scientific Results, v. 182. College Station, Texas (Ocean Drilling Program), 1-28.

Lourens, L.J., Hilgen, F. J., Shackleton, N. J., Laskar, J., Wilson, D., 2004. The Neogene Period. In: Gradstein, F. M., Ogg, J.G., Smith, A.G. (Eds.), A Geologic Time Scale 2004, Cambridge University Press, Cambridge, 409-440.

Luterbacher, H.P., Ali, J. R., Brinkhuis, H., Gradstein, F. M., Hooker, J., Monechi, S., Ogg, J. G., Powell, J., Röhl, U., Sanlippo, A., Schmitz, B., 2004. The Paleogene Period. In: Gradstein, F., Ogg, J., Smith, A. (Eds.), A Geologic Time Scale 2004. Cambridge: Cambridge University Press, 384-408.

Matsui, H., Nishi, H., Takashima, R., Kuroyanagi, A., Ikehara, M., Takayanagi, H., Iryu. Y., 2016. Changes in the depth habitat of the Oligocene planktic foraminifera (Dentoglobigerina venezuelana) induced by thermocline deepening in the eastern equatorial Pacific, Paleoceanography $31,715-731$.

Nocchi, M., Amici, E., Premoli Silva, I., 1991. Planktonic foraminiferal biostratigraphy and paleoenvironmental interpretation of Paleogene faunas from the subantarctic transect, Leg 114. In: Ciesielski, P. F., Kristoffersen, Y. et al. (Eds.), Proceedings of the Ocean Drilling Program, Scientific Results, v. 114. College Station, Texas (Ocean Drilling Program), 233-279.

Pälike, H., and 64 others, 2012, A Cenozoic record of the equatorial Pacific Ocean carbonate compensation depth. Nature 488, 609-614.

Pälike, H., Norris, R. D., Herrle, J. O., Wilson, P. A., Coxall, H. K., Lear, C.H., Shackleton, N. J., Tripati, A.K., Wade, B.S., 2006. The heartbeat of the Oligocene climate system. Science 314, 1894-1898.

Palmer, D.K., 1934. The foraminiferal genus Gümbelina in the Tertiary of Cuba. Memorias de la Sociedad Cubana de Historia Natural 8, 73-76.

Pearson, P.N., 1995. Planktonic foraminifer biostratigraphy and the development of pelagic caps on guyots in the Marshall Islands group. In: Haggerty, J. A., Premoli Silva, I., Rack, F., McNutt, M. K. (Eds.), Proceedings of the Ocean Drilling Program, Scientific Results 144. College Station, Texas (Ocean Drilling Program), 21-59.

Pearson, P. N., Chaisson, W. P., 1997. Late Paleocene to middle Miocene planktonic foraminifer biostratigraphy of the 
Ceara Rise. In: Shackleton, N.J., Curry, W.B., Richter, C., Bralower, T.J. (Eds.), Proceedings of the Ocean Drilling Program, Scientific Results 154. College Station, Texas (Ocean Drilling Program), 33-68.

Pianka, E.R., 1970. On r-and K-selection. The American Naturalist 104, 592-597.

Poore, R.Z., 1984. Middle Eocene through Quaternary Planktonic Foraminifera from the Southern Angolan Basin: Deep Sea Drilling Project Leg 73. In: Hsü, K. J., LaBrecque, J.L., et al., Initial Reports of the Deep Sea Drilling Project v.73. Washington, D.C., U.S. Government Printing Office, 429-448.

Poore, R.Z., Gosnell, L.B., 1985. Apertural features and surface texture of Upper Paleogene biserial planktonie foraminifers: links between Chiloguembelina and Streptochilus. Journal of Foraminiferal Research 15, 1-5.

Poore, R.Z., Matthews, R.K., 1984. Late Eocene-Oligocene oxygen and carbon isotope record from South Atlantic Ocean, Deep Sea Drilling Project Site 522. In: Hsü, K. J., LaBrecque, J.L., et al., Initial Reports of the Deep Sea Drilling Project, v.73, Washington, D.C., U.S. Government Printing Office, 725-735.

Poore, R.Z., Tauxe, L., Percival S.F., Jr., LaBrecque, J.L., Wright, R., Petersen, N.P., Smith, C.C., Tucker, P., Hsü, K.J., 1984. Late Cretaceous-Cenozoic Magnetostratigraphic and Biostratigraphic Correlations for the South Atlantic Ocean, Deep Sea Drilling Project Leg 73. In: Hsü, K. J., LaBrecque, J.L., et al., Initial Reports of the Deep Sea Drilling Project v. 73. Washington, D.C., U.S. Government Printing Office, 429-448.

Quilty, P.G., 1976. Planktonic foraminifera DSDP Leg 34 Nazca Plate. In: Yeats, R.S., Hart, S.R., et al., Initial Reports of the Deep Sea Drilling Project, v. 34. Washington, D.C., U.S. Government Printing Office, 629-703.

R Core Team, 2015. R: A language and environment for statistical computing. R Foundation for Statistical Computing, Vienna, Austria. Available at http://www.R-project.org/

Remane, J., Bassett, M.G., Cowie, J. W., Gohrbandt, K.H., Lane, H.R., Michelsen, O., Wang, N., 1996. Revised guidelines for the establishment of global chronostratigraphic standards by the International Commission on Stratigraphy (ICS). Episodes 19, 77-81.

Schmidt, D. N., Lazarus, D., Young, J.R., Kucera, M., 2006. Biogeography and evolution of body size in marine plankton. Earth-Science Reviews 78, 239-266.

Schmidt, D.N., Renaud, S., Bollmann, J., Schiebel, R., Thierstein, H.R., 2004a. Size distribution of Holocene planktic foraminifer assemblages: biogeography, ecology and adaptation. Marine Micropaleontology 50, 319-338.

Schmidt, D. N., Thierstein, H.R., Bollmann, J., 2004b. The evolutionary history of size variation of planktic foraminiferal assemblages in the Cenozoic. Palaeogeography, Palaeoclimatology, Palaeoecology 212, 159-180.

SeaWiFS 879 Satellite (http://oceancolor.gsfc.nasa.gov/)

Shipboard Scientific Party, 2003. Site 1237. In: Mix, A.C., Tiedemann, R., Blum, P., et al. (Eds.), Proceedings of the Ocean Drilling Program, Scientific Results, v. 202, College Station, Texas (Ocean Drilling Program), 1-107.
Stickley, C.E., Brinkhuis, H., McGonigal, K.L., Chaproniere, G.C.H., Fuller, M., Kelly, D.C., Nürnberg, D., Pfuhl, H.A., Schellenberg, S.A., Schoenfeld, J., Suzuki, N., Touchard, Y., Wei, W., Williams, G.L., Lara, J., Stant, S.A., 2004. Late Cretaceous-Quaternary biomagnetostratigraphy of ODP Sites 1168, 1170, 1171, and 1172 , Tasmanian Gateway. In: Exon, N.F., Kennett, J.P., Malone, M. J. (Eds.), Proceedings of the Ocean Drilling Program, Scientific Results, v. 189. College Station, Texas (Ocean Drilling Program), 1-57.

Stott, L.D., Kennett, J.P., 1990. Antarctic Paleogene planktonic foraminifer biostratigraphy: ODP Leg 113, Sites 689 and 690. In: Barker, P.F., Kennett, J.P., et al., Proceedings of the Ocean Drilling Program, Scientific Results, v. 113. College Station, Texas (Ocean Drilling Program), 549-569.

Van Simaeys, S., De Man, E., Vandenberghe, N., Brinkhuis, H., Steurbaut, E., 2004. Stratigraphic and palaeoenvironmental analysis of the Rupelian-Chattian transition in the type region: evidence from dinoflagellate cysts, foraminifera and calcareous nannofossils. Palaeogeography, Palaeoclimatology, Palaeoecology 208, 31-58.

Wade, B.S., Pälike, H., 2004. Oligocene climate dynamics. Paleoceanography, 19, PA4019. doi:10.1029/2004PA001 042.

Wade, B.S., Berggren, W. A., Olsson, R.K., 2007. The biostratigraphy and paleobiology of Oligocene planktonic foraminifera from, the equatorial Pacific Ocean (ODP Site 1218). Marine Micropaleontology 62, 167-179.

Wade, B.S., Pearson, P.N., Berggren, W.A., Pälike, H., 2011. Review and revision of Cenozoic tropical planktonic foraminiferal biostratigraphy and calibration to the geomagnetic polarity and astronomical time scale. Earth Science Reviews 104, 111-142.

Wade, B.S., Premec-Fucek, V., Kamikuri, S., Bartol, M., Luciani, V., Pearson, P.N., 2012. Successive extinctions of muricate planktonic foraminifera (Morozovelloides and Acarinina) mark the base Priabonian. Newsletters on Stratigraphy 45, 245-262.

Wade, B.S., Poole, C.R., Boyd, J.L., 2016. Giantism in Oligocene planktonic foraminifera Paragloborotalia opi$m a$ : Morphometric constraints from the equatorial Pacific Ocean. Newsletters on Stratigraphy 49, 421-444.

Westerhold, T., Röhl, U., Wilkens, R., Pälike, H., Lyle, M., Jones, T.D., Bown, P., Moore, T., Kamikuri, S., Acton, G., Ohneiser, C., Yamamoto, Y., Richter, C., Fitch, P., Scher, H., Liebrand, D., and the Expedition 320/321 Scientists, 2012. Revised composite depth scales and integration of IODP Sites U1331-U1334 and ODP Sites 1218-1220. In: Pälike, H., Lyle, M., Nishi, H., Raffi, I., Gamage, K., Klaus, A., and the Expedition 320/321 Scientists. Proceedings of the Integrated Ocean Drilling Program, v.320/321. Tokyo (Integrated Ocean Drilling Program Management International, Inc.). doi:10.2204/ iodp.proc.320321.201.2012.

Manuscript received: December 28, 2015

Revised version accepted: October 7, 2016 


\section{Appendix}

\section{Supplementary Information}

\section{S1. Stable Isotope Correlation for Site U1334}

In order to assess whether environmental factors had any effect on the abundance of Chiloguembelina cubensis at Site U1334 the abundance record was correlated with the oxygen and carbon isotope record from the nearby Site 1218 (Wade and Pälike 2004) and calibrate to the astronomical chronology of Pälike et al. (2006).

The two records (Figures S1 \& S2) show little correlation between Site 1218 stable isotope records and the abundance data from Site U1334. This is therefore suggestive that the abundance of C.cubensis is not controlled by palaeoceanographic changes. However, the onset of peak abundance of C.cubensis in Chron 9n correlates well with a positive shift in $\delta^{18} \mathrm{O}$ in the planktonic record which is attributed to a migration of Dentoglobigerina venezuelana to a deeper depth (Wade and Pälike 2004).

\section{References}

Pälike, H., Norris, R. D., Herrle, J.O., Wilson, P. A., Coxall, H. K., Lear, C.H., Shackleton, N. J., Tripati, A. K., Wade, B.S., 2006. The heartbeat of the Oligocene climate system. Science314, 1894-1898.

Wade, B.S., Pälike, H., 2004. Oligocene climate dynamics. Paleoceanography 19, PA4019, doi:10.1029/2004PA001042.
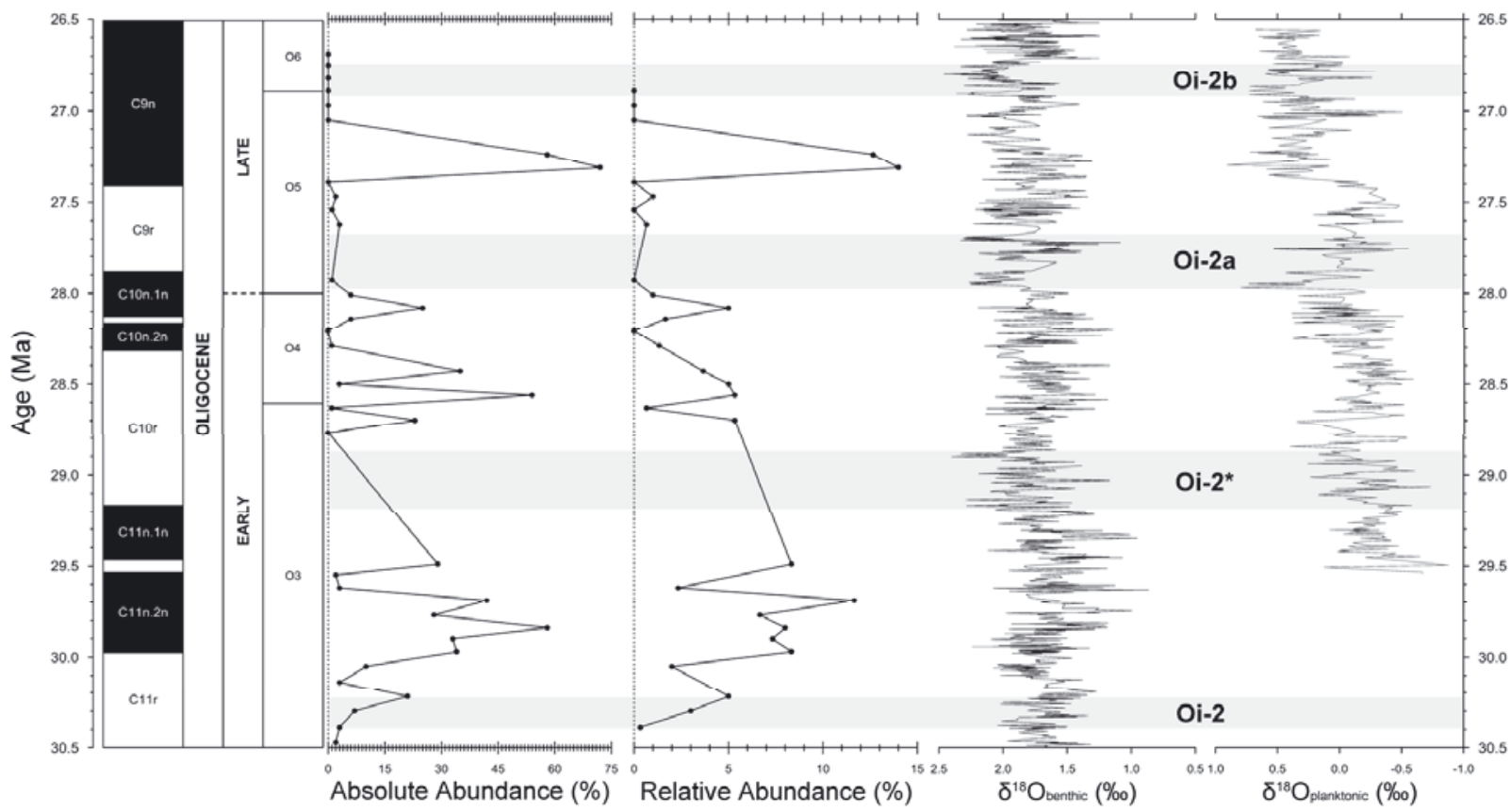

Fig. S1. Absolute and relative abundances of biserial planktonic foraminifera from Hole U1334A plotted against the $\delta^{18} \mathrm{O}$ benthic and planktonic foraminifera records, and oxygen isotope (Oi) intervals identified at ODP Leg 199 Site 1218 (Wade and Pälike 2004). 

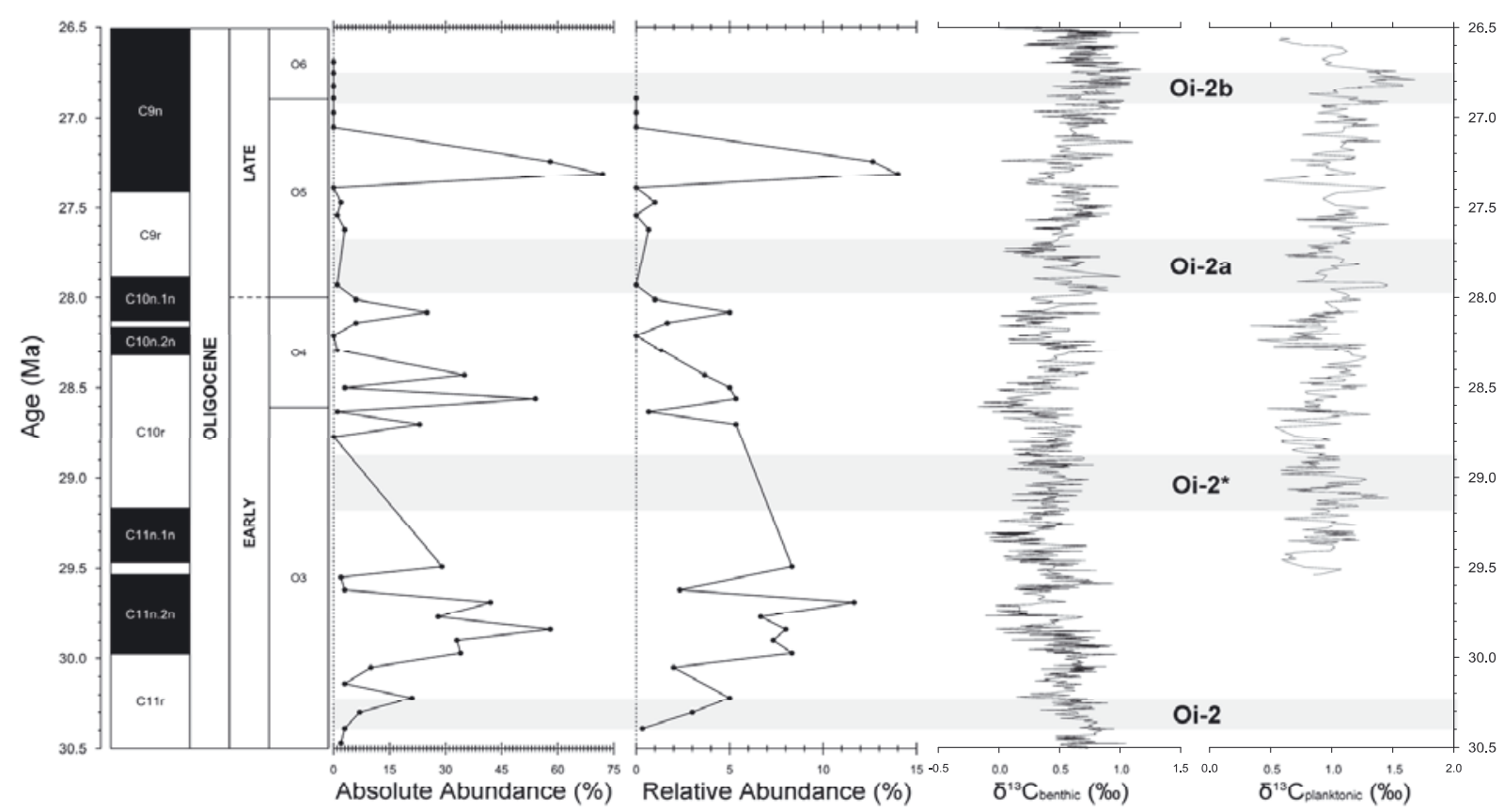

Fig. S2. Absolute and relative abundances of biserial planktonic foraminifera from Hole U1334A plotted against the $\delta^{13} \mathrm{C}$ benthic and planktonic foraminifera records, and oxygen isotope (Oi) events intervals at ODP Leg 199 Site 1218 (Wade and Pälike 2004).

Table S1 Measured test length and width for specimens from Hole 1237B, as well as the inferred aspect ratio (width/length) for each specimen. In total 59 specimens were measured from 12 core sections.

\begin{tabular}{|c|c|c|c|c|c|c|c|c|c|}
\hline $\begin{array}{l}\text { Core \& } \\
\text { Section }\end{array}$ & $\begin{array}{l}\text { Depth } \\
\text { (mbsf) }\end{array}$ & $\begin{array}{l}\text { Test } \\
\text { Length } \\
(\mu \mathrm{m})\end{array}$ & $\begin{array}{l}\text { Test } \\
\text { Width } \\
(\mu \mathrm{m})\end{array}$ & $\begin{array}{l}\text { Aspect } \\
\text { Ratio }\end{array}$ & $\begin{array}{l}\text { Core \& } \\
\text { Section }\end{array}$ & $\begin{array}{l}\text { Depth } \\
\text { (mbsf) }\end{array}$ & $\begin{array}{l}\text { Test } \\
\text { Length } \\
(\boldsymbol{\mu m})\end{array}$ & $\begin{array}{l}\text { Test } \\
\text { Width } \\
(\mu \mathrm{m})\end{array}$ & $\begin{array}{l}\text { Aspect } \\
\text { Ratio }\end{array}$ \\
\hline $\begin{array}{l}32 \mathrm{H}-1 \\
(85-87 \mathrm{~cm})\end{array}$ & 291.35 & $\begin{array}{l}115.78 \\
133.21 \\
140.67 \\
105.96 \\
141.76\end{array}$ & $\begin{array}{l}77.60 \\
71.93 \\
93.68 \\
73.40 \\
80.36\end{array}$ & $\begin{array}{l}0.67 \\
0.54 \\
0.67 \\
0.69 \\
0.57\end{array}$ & $\begin{array}{l}32 \mathrm{H}-3 \\
(35-37 \mathrm{~cm})\end{array}$ & 293.88 & $\begin{array}{l}179.02 \\
188.85 \\
122.63 \\
111.57 \\
169.47\end{array}$ & $\begin{array}{r}119.49 \\
94.99 \\
82.02 \\
73.98 \\
99.42\end{array}$ & $\begin{array}{l}0.67 \\
0.50 \\
0.67 \\
0.66 \\
0.59\end{array}$ \\
\hline $\begin{array}{l}32 \mathrm{H}-2 \\
(35-37 \mathrm{~cm})\end{array}$ & 292.37 & $\begin{array}{l}147.07 \\
156.99 \\
140.00 \\
157.89 \\
114.25\end{array}$ & $\begin{array}{r}74.69 \\
92.80 \\
91.62 \\
115.76 \\
77.80\end{array}$ & $\begin{array}{l}0.51 \\
0.59 \\
0.65 \\
0.73 \\
0.68\end{array}$ & $\begin{array}{l}32 \mathrm{H}-3 \\
(85-87 \mathrm{~cm})\end{array}$ & 294.38 & $\begin{array}{l}115.30 \\
135.23 \\
125.47 \\
117.93 \\
118.78\end{array}$ & $\begin{array}{l}64.91 \\
88.94 \\
90.18 \\
83.70 \\
94.01\end{array}$ & $\begin{array}{l}0.56 \\
0.66 \\
0.72 \\
0.71 \\
0.79\end{array}$ \\
\hline $\begin{array}{l}32 \mathrm{H}-2 \\
(85-87 \mathrm{~cm})\end{array}$ & 292.87 & $\begin{array}{l}122.96 \\
136.04 \\
118.28 \\
132.93 \\
144.26\end{array}$ & $\begin{array}{l}93.27 \\
73.10 \\
81.65 \\
81.25 \\
94.45\end{array}$ & $\begin{array}{l}0.76 \\
0.54 \\
0.69 \\
0.61 \\
0.65\end{array}$ & $\begin{array}{l}32 \mathrm{H}-5 \\
(85-87 \mathrm{~cm})\end{array}$ & 297.39 & $\begin{array}{l}109.56 \\
121.57 \\
123.66 \\
139.11 \\
118.22\end{array}$ & $\begin{array}{l}76.09 \\
89.08 \\
71.49 \\
94.14 \\
79.04\end{array}$ & $\begin{array}{l}0.69 \\
0.73 \\
0.58 \\
0.68 \\
0.67\end{array}$ \\
\hline $\begin{array}{l}32 \mathrm{H}-2 \\
(135-137 \mathrm{~cm})\end{array}$ & 293.37 & $\begin{array}{l}194.12 \\
141.08 \\
137.34 \\
153.93 \\
154.82\end{array}$ & $\begin{array}{l}92.11 \\
63.31 \\
87.79 \\
93.74 \\
89.48\end{array}$ & $\begin{array}{l}0.47 \\
0.45 \\
0.64 \\
0.61 \\
0.58\end{array}$ & $\begin{array}{l}33 \mathrm{H}-1 \\
(85-87 \mathrm{~cm})\end{array}$ & 300.85 & $\begin{array}{l}116.85 \\
160.24 \\
128.02 \\
134.37 \\
107.28\end{array}$ & $\begin{array}{l}80.15 \\
84.95 \\
88.47 \\
81.13 \\
73.03\end{array}$ & $\begin{array}{l}0.69 \\
0.53 \\
0.69 \\
0.60 \\
0.68\end{array}$ \\
\hline
\end{tabular}


Table S1 Continued.

\begin{tabular}{|c|c|c|c|c|c|c|c|c|c|}
\hline $\begin{array}{l}\text { Core \& } \\
\text { Section }\end{array}$ & $\begin{array}{l}\text { Depth } \\
\text { (mbsf) }\end{array}$ & $\begin{array}{l}\text { Test } \\
\text { Length } \\
(\mu \mathrm{m})\end{array}$ & 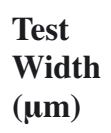 & $\begin{array}{l}\text { Aspect } \\
\text { Ratio }\end{array}$ & $\begin{array}{l}\text { Core \& } \\
\text { Section }\end{array}$ & $\begin{array}{l}\text { Depth } \\
\text { (mbsf) }\end{array}$ & $\begin{array}{l}\text { Test } \\
\text { Length } \\
(\mu \mathrm{m})\end{array}$ & $\begin{array}{l}\text { Test } \\
\text { Width } \\
(\mu \mathrm{m})\end{array}$ & $\begin{array}{l}\text { Aspect } \\
\text { Ratio }\end{array}$ \\
\hline $\begin{array}{l}33 \mathrm{H}-3 \\
(85-87 \mathrm{~cm})\end{array}$ & 303.87 & $\begin{array}{l}135.73 \\
124.73 \\
153.53 \\
107.78\end{array}$ & $\begin{array}{l}73.57 \\
91.97 \\
89.11 \\
71.77\end{array}$ & $\begin{array}{l}0.54 \\
0.74 \\
0.58 \\
0.67\end{array}$ & $\begin{array}{l}34 \mathrm{H}-3 \\
(85-87 \mathrm{~cm})\end{array}$ & 313.35 & $\begin{array}{l}167.53 \\
127.20 \\
144.28 \\
110.98 \\
130.27\end{array}$ & $\begin{array}{l}86.59 \\
66.62 \\
87.20 \\
71.53 \\
75.17\end{array}$ & $\begin{array}{l}0.52 \\
0.52 \\
0.60 \\
0.64 \\
0.58\end{array}$ \\
\hline $\begin{array}{l}34 \mathrm{H}-1 \\
(85-87 \mathrm{~cm})\end{array}$ & 310.35 & $\begin{array}{l}172.75 \\
113.58 \\
149.53 \\
164.81 \\
126.93\end{array}$ & $\begin{array}{r}100.69 \\
73.66 \\
79.81 \\
106.98 \\
83.47\end{array}$ & $\begin{array}{l}0.58 \\
0.65 \\
0.53 \\
0.65 \\
0.66\end{array}$ & $\begin{array}{l}34 \mathrm{H}-5 \\
(85-87 \mathrm{~cm})\end{array}$ & 316.37 & $\begin{array}{l}200.35 \\
166.35 \\
167.59 \\
144.79 \\
203.20\end{array}$ & $\begin{array}{l}144.71 \\
123.82 \\
126.19 \\
101.13 \\
133.38\end{array}$ & $\begin{array}{l}0.72 \\
0.74 \\
0.75 \\
0.70 \\
0.66\end{array}$ \\
\hline
\end{tabular}

Table S2 Measured test length and width for specimens from Hole U1334A, as well as the inferred aspect ratio (width/ length) for each specimen. In total 69 specimens were measured from 14 core sections.

\begin{tabular}{|c|c|c|c|c|c|c|c|c|c|}
\hline $\begin{array}{l}\text { Core \& } \\
\text { Section }\end{array}$ & $\begin{array}{l}\text { Depth } \\
\text { (m } \\
\text { CCSF-A) }\end{array}$ & $\begin{array}{l}\text { Test } \\
\text { Length } \\
(\mu \mathrm{m})\end{array}$ & $\begin{array}{l}\text { Test } \\
\text { Width } \\
\text { ( } \mu \mathrm{m})\end{array}$ & $\begin{array}{l}\text { Aspect } \\
\text { Ratio }\end{array}$ & $\begin{array}{l}\text { Core \& } \\
\text { Section }\end{array}$ & $\begin{array}{l}\text { Depth } \\
\text { (m } \\
\text { CCSF-A) }\end{array}$ & $\begin{array}{l}\text { Test } \\
\text { Length } \\
(\mu \mathrm{m})\end{array}$ & $\begin{array}{l}\text { Test } \\
\text { Width } \\
(\mu \mathrm{m})\end{array}$ & $\begin{array}{l}\text { Aspect } \\
\text { Ratio }\end{array}$ \\
\hline $\begin{array}{l}17 \mathrm{H}-1 \\
(43-45 \mathrm{~cm})\end{array}$ & 174.06 & $\begin{array}{l}204.05 \\
206.18 \\
143.12 \\
227.95 \\
184.87\end{array}$ & $\begin{array}{l}114.86 \\
104.57 \\
128.46 \\
147.46 \\
122.24\end{array}$ & $\begin{array}{l}0.56 \\
0.51 \\
0.90 \\
0.65 \\
0.66\end{array}$ & $\begin{array}{l}19 \mathrm{H}-5 \\
(43-45 \mathrm{~cm})\end{array}$ & 202.48 & $\begin{array}{l}140.99 \\
171.02 \\
198.34 \\
182.43 \\
193.29\end{array}$ & $\begin{array}{l}94.32 \\
124.22 \\
140.39 \\
95.10 \\
133.98\end{array}$ & $\begin{array}{l}0.67 \\
0.73 \\
0.71 \\
0.52 \\
0.69\end{array}$ \\
\hline $\begin{array}{l}17 \mathrm{H}-2 \\
(43-45 \mathrm{~cm})\end{array}$ & 175.47 & $\begin{array}{l}227.56 \\
203.41 \\
200.14 \\
185.21 \\
201.10\end{array}$ & $\begin{array}{l}162.17 \\
122.13 \\
121.44 \\
140.95 \\
130.65\end{array}$ & $\begin{array}{l}0.71 \\
0.60 \\
0.61 \\
0.76 \\
0.65\end{array}$ & $\begin{array}{l}20 \mathrm{H}-1 \\
(43-45 \mathrm{~cm})\end{array}$ & 220.24 & $\begin{array}{l}205.98 \\
192.31 \\
180.33 \\
218.24 \\
153.83\end{array}$ & $\begin{array}{l}130.54 \\
140.99 \\
143.68 \\
162.93 \\
126.71\end{array}$ & $\begin{array}{l}0.63 \\
0.73 \\
0.80 \\
0.75 \\
0.82\end{array}$ \\
\hline $\begin{array}{l}18 \mathrm{H}-4 \\
(43-45 \mathrm{~cm})\end{array}$ & 189.24 & $\begin{array}{l}193.97 \\
228.03 \\
167.91 \\
122.47 \\
147.77\end{array}$ & $\begin{array}{l}119.19 \\
137.35 \\
93.13 \\
76.72 \\
107.65\end{array}$ & $\begin{array}{l}0.61 \\
0.60 \\
0.55 \\
0.63 \\
0.73\end{array}$ & $\begin{array}{l}20 \mathrm{H}-4 \\
(43-45 \mathrm{~cm})\end{array}$ & 224.6 & $\begin{array}{l}207.87 \\
225.87 \\
227.65 \\
211.23 \\
164.18\end{array}$ & $\begin{array}{l}160.73 \\
171.79 \\
162.11 \\
156.57 \\
110.18\end{array}$ & $\begin{array}{l}0.77 \\
0.76 \\
0.71 \\
0.74 \\
0.67\end{array}$ \\
\hline $\begin{array}{l}19 \mathrm{H}-1 \\
(43-45 \mathrm{~cm})\end{array}$ & 196.56 & $\begin{array}{l}150.38 \\
189.76 \\
135.94 \\
181.02 \\
220.10\end{array}$ & $\begin{array}{l}77.31 \\
130.77 \\
91.22 \\
104.50 \\
118.02\end{array}$ & $\begin{array}{l}0.51 \\
0.69 \\
0.67 \\
0.58 \\
0.54\end{array}$ & $\begin{array}{l}20 \mathrm{H}-5 \\
(43-45 \mathrm{~cm})\end{array}$ & 226.1 & $\begin{array}{l}224.96 \\
178.93 \\
226.86 \\
191.80 \\
250.21\end{array}$ & $\begin{array}{l}144.17 \\
127.78 \\
154.54 \\
140.30 \\
147.68\end{array}$ & $\begin{array}{l}0.64 \\
0.71 \\
0.68 \\
0.73 \\
0.59\end{array}$ \\
\hline $\begin{array}{l}19 \mathrm{H}-3 \\
(43-45 \mathrm{~cm})\end{array}$ & 199.48 & $\begin{array}{l}172.69 \\
219.87 \\
157.88 \\
164.14 \\
208.13\end{array}$ & $\begin{array}{l}85.16 \\
113.81 \\
94.79 \\
104.14 \\
90.53\end{array}$ & $\begin{array}{l}0.49 \\
0.52 \\
0.60 \\
0.63 \\
0.43\end{array}$ & $\begin{array}{l}20 \mathrm{H}-6 \\
(43-45 \mathrm{~cm})\end{array}$ & 227.6 & $\begin{array}{l}170.64 \\
167.88 \\
141.74 \\
151.91 \\
173.18\end{array}$ & $\begin{array}{l}106.27 \\
124.89 \\
104.59 \\
119.39 \\
116.21\end{array}$ & $\begin{array}{l}0.62 \\
0.74 \\
0.74 \\
0.79 \\
0.67\end{array}$ \\
\hline
\end{tabular}


Table S2 Continued.

\begin{tabular}{lllll}
\hline $\begin{array}{l}\text { Core \& } \\
\text { Section }\end{array}$ & $\begin{array}{l}\text { Depth } \\
(\mathbf{m}\end{array}$ & $\begin{array}{l}\text { Test } \\
\text { Length } \\
\text { CCSF-A) }\end{array}$ & $\begin{array}{l}\text { Test } \\
\text { Width })\end{array}$ & $\begin{array}{l}\text { Aspect } \\
\text { Ratio }\end{array}$ \\
& & $\boldsymbol{\mu m})$ & \\
\hline $20 \mathrm{H}-7$ & 228.9 & 251.98 & 139.02 & 0.55 \\
$(43-45 \mathrm{~cm})$ & & 127.80 & 100.89 & 0.79 \\
& & 171.97 & 107.49 & 0.63 \\
& & 174.80 & 106.01 & 0.61 \\
& & 188.24 & 115.68 & 0.61 \\
\hline $21 \mathrm{H}-1$ & 230.28 & 201.72 & 128.10 & 0.64 \\
$(43-45 \mathrm{~cm})$ & & 180.40 & 138.75 & 0.77 \\
& & 165.48 & 127.91 & 0.77 \\
& & 238.88 & 151.44 & 0.63 \\
& & 201.67 & 169.83 & 0.84 \\
\hline
\end{tabular}

\begin{tabular}{|c|c|c|c|c|}
\hline $\begin{array}{l}\text { Core \& } \\
\text { Section }\end{array}$ & $\begin{array}{l}\text { Depth } \\
\text { (m } \\
\text { CCSF-A) }\end{array}$ & $\begin{array}{l}\text { Test } \\
\text { Length } \\
(\boldsymbol{\mu m})\end{array}$ & $\begin{array}{l}\text { Test } \\
\text { Width } \\
(\boldsymbol{\mu m})\end{array}$ & $\begin{array}{l}\text { Aspect } \\
\text { Ratio }\end{array}$ \\
\hline $\begin{array}{l}21 \mathrm{H}-2 \\
(43-45 \mathrm{~cm})\end{array}$ & 231.8 & $\begin{array}{l}199.64 \\
195.79 \\
164.40 \\
176.57\end{array}$ & $\begin{array}{l}168.71 \\
158.37 \\
142.45 \\
136.24\end{array}$ & $\begin{array}{l}0.85 \\
0.81 \\
0.87 \\
0.77\end{array}$ \\
\hline $\begin{array}{l}21 \mathrm{H}-4 \\
(43-45 \mathrm{~cm})\end{array}$ & 234.8 & $\begin{array}{l}214.61 \\
251.80 \\
258.95 \\
170.33 \\
233.35\end{array}$ & $\begin{array}{l}148.96 \\
165.59 \\
163.36 \\
134.45 \\
155.32\end{array}$ & $\begin{array}{l}0.69 \\
0.66 \\
0.63 \\
0.79 \\
0.67\end{array}$ \\
\hline
\end{tabular}

Hole 1237B

Hole U1334A
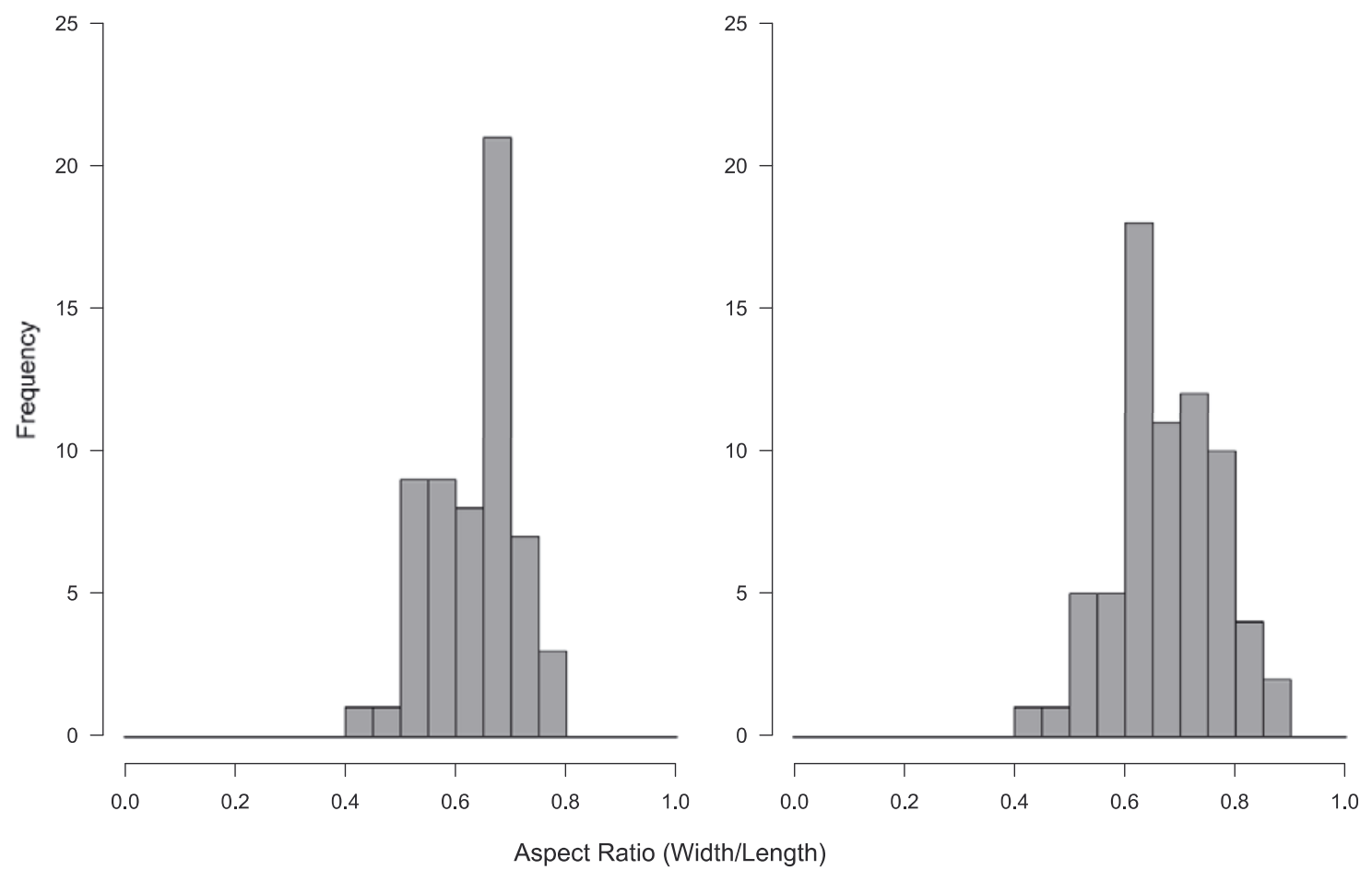

Fig. S3. Aspect Ratios for measured specimens at Hole 1237B and Hole U1334A, illustrating the greater spread of test sizes at Site U1334. 